\title{
BUCKLEY IS DEAD, LONG LIVE BUCKLEY: THE NEW CAMPAIGN FINANCE INCOHERENCE OF MCCONNELL $V$. FEDERAL ELECTION COMMISSION
}

\author{
RICHARD L. HASEN ${ }^{\dagger}$
}

The Supreme Court's recent decision in McConnell v. Federal Election Commission ${ }^{1}$ marks the culmination of an effort begun in 2000 to shift the Court's campaign finance jurisprudence in an important, though potentially dangerous, direction. Under pre-2000 jurisprudence, the Court (with one notable exception) ${ }^{2}$ upheld campaign finance laws only when the government demonstrated, with a reasonable amount of evidence, that the laws were closely drawn to prevent corruption or the appearance of corruption. The new jurisprudence, while purporting to apply the same anticorruption standard, does so with a new and extensive deference to legislative judgments on both the need for campaign finance regulation and the proper means to achieve it.

There are signs that this shift is not merely the slipping of existing standards. Rather, it appears that the Court's jurisprudence is moving in the direction proposed by Justice Breyer, toward upholding campaign finance laws that promote a kind of political equality. Justice Breyer termed the rationale a "general participatory self-government objective," and explained its aim "to democratize the influence that money can bring to bear upon the electoral process, thereby building

\footnotetext{
${ }^{\dagger}$ Professor and William M. Rains Fellow, Loyola Law School, Los Angeles. I filed a pro bono brief amicus curiae in the United States Supreme Court on behalf of the Center for Governmental Studies supporting some of the disclosure and issue advocacy provisions of the Bipartisan Campaign Reform Act of 2002 at issue in McConnell v. FEC, 540 U.S. 93, 124 S. Ct. 619 (2003) (amicus brief available at 2003 WL 21767992). The views expressed here are mine alone and not those of the Center for Governmental Studies. I benefited greatly in writing this Article from conversations and correspondence with Marty Lederman. Thanks also to Richard Epstein, Dan Lowenstein, Rick Pildes, Eric Rasmusen, Roy Schotland, participants at the University of Pennsylvania Law Review symposium on Law and Democracy, and workshop participants at Indiana University and Loyola Marymount University for useful comments and suggestions.

${ }^{1} 540$ U.S. 93, 124 S. Ct. 619 (2003).

${ }^{2}$ See infra Part I.B (discussing Austin v. Mich. State Chamber of Commerce, 494 U.S. $652(1990))$.

${ }^{3}$ Stephen Breyer, Our Democratic Constitution, 77 N.Y.U. L. REv. 245, 252 (2002).
} 
public confidence in that process, broadening the base of a candidate's meaningful financial support, and encouraging greater public participation." ${ }^{4}$

This apparent shift might be welcome news for those who believe that the Court was previously too restrictive of efforts to limit the role of money in politics in order to promote greater political equality. ${ }^{5}$ But the means by which the Court has undertaken this shift have proven problematic. The Court has continued to entertain the fiction that it is adhering to the anticorruption rationale of Buckley $v$. Valeo, ${ }^{6}$ perhaps because one or two members of the five-Justice majority making the shift in McConnell may be unwilling (at least now) to expressly embrace Justice Breyer's participatory self-government rationale. ${ }^{7}$ In order to uphold bolder campaign finance laws purportedly under the Buckley standard, the Court has: (1) reduced the evidentiary burden that the government must meet to show that a law is necessary to combat corruption or its appearance; (2) relaxed the level of scrutiny applicable to reviewing campaign finance regulation; and (3) especially in the McConnell case, engaged in unusually sloppy and incomplete reasoning to justify its holdings. The result is jurisprudential incoherence and a lead opinion in the most important campaign

${ }^{4} I d$. at 253.

${ }^{5}$ I have written in favor of the equality rationale in a number of places, including Richard L. Hasen, Clipping Coupons for Democracy: An Egalitarian/Public Choice Defense of Campaign Finance Vouchers, 84 CAL. L. REV. 1 (1996) [hereinafter Hasen, Clipping Coupons], and Richard L. Hasen, Campaign Finance Laws and the Rupert Murdoch Problem, 77 Tex. L. Rev. 1627 (1999) [hereinafter Hasen, Rupert Murdoch Problem].

${ }^{6} 424$ U.S. 1 (1976) (per curiam).

${ }^{7}$ Justice Ginsburg joined Justice Breyer's concurrence in the 2000 case, Nixon v. Shrink Missouri Government PAC (Shrink Missouri), 528 U.S. 377, 399 (2000) (Breyer, J., concurring), setting forth the participatory self-government rationale. Justice Stevens, joined by Justice Ginsburg, endorsed an equality rationale for campaign finance earlier in Colorado Republican Federal Campaign Committee v. FEC (Colorado I), 518 U.S. 604, 649 (1996) (Stevens, J., dissenting), which has at least some overlap with the participatory self-government rationale. Justice Souter has never explicitly endorsed the participatory self-government rationale, though he wrote the majority opinions in three of the four cases shifting the Court's jurisprudence in its direction. See FEC v. Beaumont, 539 U.S. 146 (2003) (Souter, J.); FEC v. Colo. Republican Fed. Campaign Comm. (Colorado II), 533 U.S. 431 (2001) (Souter, J.); Shrink Missouri (Souter, J.); see also infra Part I.C (discussing these three cases). This leaves Justice O'Connor, who before McConnell had written very few words in the many campaign finance cases she has considered since she joined the Court and has now shifted her position three times on the constitutionality of limiting corporate election-related expenditures. See DANIEL H. LOWENSTEIN \& Richard L. Hasen, Election Law: CASES AND Materials 853, 952 (3d ed. 2004) (discussing Justice O'Connor's position shift among FEC v. Massachusetts, Citizens for Life, Inc., Austin v. Michigan State Chamber of Commerce, and McConnell). 
finance case in a generation that appears to pay only cursory attention to the First Amendment interests that must be balanced in evaluating any campaign finance regime.

Justice Breyer, in setting forth his participatory self-government rationale, has noted the Court's important role both in balancing competing constitutional interests and in "evaluating the risk that reform legislation will defeat the very objective of participatory selfgovernment itself; for example, where laws would set limits so low that by elevating the reputation-related or media-related advantages of incumbency to the point where they would insulate incumbents from effective challenge." The Court, however, has failed to meaningfully balance or closely examine new campaign finance laws for selfdealing. Indeed, in McConnell, the Court in the joint majority opinion $^{9}$ appears to abdicate its role in this regard, hiding behind platitudes about evidentiary burdens and levels of scrutiny in upholding various aspects of the Bipartisan Campaign Reform Act of 2002 (BCRA). ${ }^{10}$

Three examples demonstrate McConnell's failure. First, the joint majority opinion cannot persuasively explain under the Buckley anticorruption standard why it is permissible for Congress to regulate the fundraising and spending of local political parties and candidates absent any evidence that local political parties or candidates can serve as conduits for corruption of federal officials. The majority's attempt to distinguish the activities of political talk show hosts and newspaper editors as non-regulable only further muddles the analysis. Second, the joint majority opinion fails to engage in a serious analysis of the potential overbreadth issues raised by regulating election-time advertisements that may not in fact be intended to influence and may not even affect federal elections. Thus, the majority never expressly considers whether the statute, under Justice Breyer's standard, "strike[s] a

\footnotetext{
${ }^{8}$ Breyer, supra note 3, at 254; see also Shrink Missouri, 528 U.S. at 403-04 (Breyer, J., concurring) ("We should defer to [the legislature's] political judgment that unlimited spending threatens the integrity of the electoral process. But we should not defer in respect to whether its solution ... significantly increases the reputation-related or media-related advantages of incumbency and thereby insulates legislators from effective electoral challenge.")

${ }^{9}$ In speaking of the "joint majority opinion" in McConnell, I refer to the Court's opinion discussing the constitutionality of Titles I and II of BCRA, jointly authored by Justices Stevens and O'Connor. Chief Justice Rehnquist authored the opinion for the Court on BCRA Titles III and IV, and Justice Breyer authored the opinion for the Court on BCRA Title V.

${ }^{10}$ Pub. L. No. 107-171, 101, 116 Stat. 81, 82 (codified at 2 U.S.C.A. § 441i(a) (Supp. 2003)).
} 
reasonable balance between [its] electoral speech-restricting and speech-enhancing consequences." ${ }^{11}$ Third, the joint majority opinion never even mentions, much less explains, how the rationale that would support regulating corporate-funded election-related spending could apply to union-funded election-related spending. ${ }^{12}$

The participatory self-government rationale may provide a persuasive reason for the Court to have upheld these provisions. But the analysis is difficult and subtle. Shoehorning it into a Buckley anticorruption analysis has done everyone a disservice, giving short shrift to competing First Amendment values and threatening to undermine the very participatory self-government goals favored by at least some members of the McConnell majority.

This Article proceeds as follows. Part I briefly surveys the preMcConnell campaign finance jurisprudence, contrasting Buckley and the pre-2000 cases on the one hand, with the Court's three post-2000, pre-McConnell cases on the other. The recent trend, even before McConnell, is inconsistent with the Buckley rationale, at least as Buckley has been traditionally understood. The Court has replaced a general skepticism of campaign finance regulation with unprecedented deference to legislative determinations on both the need for regulation and the means best suited to achieve regulatory goals.

Part II uses three examples from the McConnell joint majority opinion to demonstrate how the case fits into the new deferential post-2000 campaign finance jurisprudence.

Part III points to signs apparent in the post-2000 jurisprudence, and intensified in McConnell, that the Court is moving toward endorsing the participatory self-government rationale for campaign finance regulation.

Part IV argues that that if indeed the Court is moving toward endorsement of the participatory self-government rationale, it should do so more carefully. Thus far, the Court has given only lip service to the requirement that it balance competing interests and police campaign finance measures for legislative self-dealing. Had the Court engaged in such balancing and policing in McConnell, it might have articulated

${ }^{11}$ Breyer, supra note 3, at 253.

${ }^{12}$ The majority opinion is muddled on the issue of disclosure as well, a point I tackle in Richard L. Hasen, The Surprisingly Easy Case for Disclosure of Contributions and Expenditures Funding Sham Issue Advocacy, 3 ElECTION L.J. 251 (2004). See also Elizabeth Garrett, McConnell v. FEC and Disclosure, 3 ELECTION L.J. 237, 238 (2004) (arguing "that McConnell v. FEC will protect most disclosure statutes from First Amendment challenges and allow reformers to adopt even more sweeping requirements"). 
a more coherent and subtle explanation for upholding-or perhaps even struck down some of-the major provisions of BCRA. At the very least, had the Court engaged in more careful analysis it would not have been faulted for giving First Amendment concerns short shrift. Part IV concludes by examining the danger that the Court eventually will eviscerate the distinction between contributions and expenditures without taking into account a key requirement of the participatory self-government rationale: the need for vibrant election-related participation by a large group of non-governmental actors. In particular, Part IV concludes that the Court should be wary of approving any additional expenditure limits that are not coupled with a leveling-up mechanism, such as a broad public financing program.

Depending upon the next appointments to the Supreme Court, the campaign finance jurisprudential shift, currently hanging by a one-vote majority, could be short-lived or long-lived. At least for the near term, and perhaps for much longer, it will be important to bring some coherence to the Court's analysis in this area. This Article is a modest effort in this regard.

\section{BEFore MCCONNELL: THE SLOW DEATH OF BUCKLEY}

\section{A. From Buckley into the 1980s: Court Skepticism of Campaign Finance Regulation}

If, as it appears, McConnell was a compromise decision drafted to take into account the competing and sometimes contradictory views of the members of its majority, it is in good company. Buckley itself was drafted by committee, and some of its internal inconsistencies may best be explained by tensions in reasoning among the authors of its various parts. ${ }^{13}$

The majority and dissenting opinions in McConnell devote many pages to debating the joint majority opinion's fidelity-or lack

${ }^{13}$ See Richard L. Hasen, The Untold Drafting History of Buckley v. Valeo, 2 ELECTION L.J. 241 (2003) (relating a chronology of the Court's internal deliberations concerning Buckley, from the post-argument conference to the issuance of the decision). The muddled reasoning in Austin v. Michigan Chamber of Commerce, 494 U.S. 652 (1990), may also be explained as the result of political compromise. See RICHARD L. HASEN, THE SUPREME COURT AND ELECTION LAW: JUDGING EQUALITY FROM BAKER V. CARR TO Bush V. GORE 113-14 (2003) [hereinafter Hasen, Supreme COURT \& Election LaW] (tracing Austin's drafting history). 
thereof-to Buckley; ${ }^{14}$ legal commentators have also begun tackling this issue. ${ }^{15}$ Therefore, this Part gives only a brief description intended to show the shift from past to present ${ }^{16}$ and to orient readers unfamiliar with the campaign finance landscape to the important precedents discussed throughout the rest of this Article. Readers already familiar with the major campaign finance decisions may wish to skip to Part II.

The Supreme Court's 1976 Buckley case considered the constitutionality of much of the 1974 Amendments to the Federal Election

${ }^{14}$ Compare McConnell, 124 S. Ct. at 655-58 (joint majority opinion) (describing how the standards set forth in Buckley apply to the McConnell decision), with 124 S. Ct. at 744-49 (Kennedy, J., concurring in part and dissenting in part) (arguing that the majority improperly extends the reasoning of Buckley).

${ }^{15}$ See, e.g., Robert F. Bauer, McConnell, Parties, and the Decline of the Right of Association, 3 ELECTION L.J. 199, 204 (2004) (arguing that the notion of deference in McConnell is a departure from Buckley, but that both cases take a similarly narrow view of the right of association); Robert F. Bauer, When "the Pols Make the Calls": McConnell's Theory of Judicial Deference in the Twilight of Buckley, 153 U. PA. L. REV. 5,17 (2004) (examining the relationship between the reasoning of Buckley and the notion of deference in McConnell); Lillian R. BeVier, McConnell v. FEC: Not Senator Buckley's First Amendment, 3 ELECTION L.J. 127, 128 (2004) (arguing that McConnell discarded Buckley's underlying premises and almost entirely dismantled the limits that Buckley imposed on the power of legislatures to regulate speech during political campaigns); Richard Briffault, McConnell v. FEC and the Transformation of Campaign Finance Law, 3 ELECTION L.J. 147 (2004) (arguing that McConnell was, in different respects, both an extension of and a departure from Buckley); Samuel Issacharoff, Throwing in the Towel: The Constitutional Morass of Campaign Finance, 3 ELECTION L.J. 259, 261 (2004) ("[T] here can be little doubt, after Buckley, that there must be a significant rights overlay to the expressive dimension of campaign finance regulation.... A striking feature of McConnell is the almost complete absence of such conventional First Amendment concerns."); Daniel H. Lowenstein, BCRA and McConnell in Perspective, 3 Election L.J. 277, 282 (2004) ("Buckley is not only not dead, it may not be dying at all."); Daniel R. Ortiz, The Unbearable Lightness of Being McConnell, 3 ELECTION L.J. 299, 301 (2004) (arguing that McConnell embraced Buckley's rules while implicitly rejecting its rationale); Spencer Overton, Judicial Modesty and the Lessons of McConnell v. FEC, 3 ELECTION L.J. 305, 30509, 314 (2004) (arguing that McConnell was faithful to Buckley, and that McConnell was an example of the Court "remaining true to its past opinions"); Roy A. Schotland, Act I: BCRA Wins in Congress. Act II: BCRA Wins Big at the Court. Act III: BCRA Loses to Reality, 3 ELECTION L.J. 335, 336 (2004) (arguing that McConnell was a departure from Buckley); Bradley A. Smith, McConnell v. Federal Election Commission: Ideology Trumps Reality, Pragmatism, 3 ELECTION L.J. 345, 346-47 (2004) (“[BCRA] restores neither the system passed by Congress in 1974 nor that system as trimmed back by Buckley"); Ellen L. Weintraub, Perspectives on Corruption, 3 ELECTION L.J. 355, 359-60 (2004) (arguing that Mc Connell was a departure from Buckley).

${ }^{16}$ Some of the descriptions of the pre-McConnell case law below appear in slightly different form in HASEN, SUPREME COURT \& ELECTION LAW, supra note 13, at 105-14. For a fuller description of the campaign finance jurisprudence, see LOWENSTEIN \& HASEN, supra note 7, at 717-1024. 
Campaign Act (FECA). ${ }^{17}$ The FECA Amendments were complex; they provided for, among other things: (1) limits on the amounts that individuals or organizations could contribute to candidates ("contribution limits") $;^{18}$ (2) limits on the amounts that individuals or organizations could spend, independently of candidates, to support or oppose candidates for federal office ("expenditure limits"); $;^{19}$ (3) public financing for major presidential candidates; ${ }^{20}$ and (4) the creation of the Federal Election Commission. ${ }^{21}$ The Court upheld FECA's contribution limits, struck down the expenditure limits, upheld the public financing system, and struck down the means for the appointment of members of the FEC. ${ }^{22}$

Most notable for our purposes is the Court's decision to uphold the campaign contribution limits but to strike down the expenditure limits. Although recognizing that any law regulating campaign financing was subject to the "exacting scrutiny required by the First Amendment, ${ }^{, 23}$ the Court mandated divergent treatment of contributions and expenditures for two reasons. First, the Court held that campaign expenditures were core political speech, but a limit on the amount of campaign contributions only marginally restricted a contributor's ability to send a message of support for a candidate. ${ }^{24}$ Thus, expenditures were entitled to greater constitutional protection than contributions. Second, the Buckley Court recognized only the interests in preventing corruption and the appearance of corruption as justifying infringement on First Amendment rights. ${ }^{25}$

The Court held that large contributions raise the problem of corruption " $[\mathrm{t}]$ o the extent that large contributions are given to secure a

${ }^{17}$ Federal Election Campaign Act of 1974, Pub. L. No. 93-443, 88 Stat. 1263 (codified as amended at 2 U.S.C. $\$ \S 431-55$ (2002)). The 1974 Amendments amended the Federal Election Campaign Act of 1971, Pub. L. No. 92-225, 86 Stat. 3 (1972).

${ }_{18}^{18}$ See Buckley, 424 U.S. at 13 n.12 (citing relevant statutory provisions).

${ }^{19}$ See id. at 13 nn.13-15 (citing relevant statutory provision). FECA now treats spending in coordination with candidates as a contribution, not as an expenditure. See 2 U.S.C. $\$ 441 \mathrm{a}(\mathrm{a})(7)$ (B) (i) ("For purposes of this subsection ... expenditures made by any person in cooperation, consultation, or concert, with, or at the request or suggestion of, a candidate, his authorized political committees, or their agents, shall be considered to be a contribution to such candidate.").

${ }^{20}$ See Buckley, 424 U.S. at 85-86 n.114 (summarizing the relevant provisions).

${ }^{21}$ See id. at 109 (summarizing the relevant provisions).

${ }^{22} I d$. at 143 .

${ }^{23} I d$. at 16 (citations omitted).

${ }^{24}$ Id. at 21.

${ }^{25} I d$. at $26,45-48$. 
political quid pro quo from current and potential officeholders." ${ }^{26}$ But truly independent expenditures do not raise the same danger of corruption, because a quid pro quo is less attainable if politician and spender cannot communicate about the expenditure. ${ }^{27}$

With the corruption interest having failed to justify a limit upon independent expenditures, the Court considered the alternative argument that expenditure limits were justified by "the ancillary governmental interest in equalizing the relative ability of individuals and groups to influence the outcome of elections." ${ }^{28}$ In one of the most famous (some would say notorious) sentences in Buckley, the Court rejected this equality rationale for campaign finance regulation, at least in the context of expenditure limits: "[T] he concept that government may restrict the speech of some elements of our society in order to enhance the relative voice of others is wholly foreign to the First Amendment." ${ }^{29}$

Portions of Buckley certainly show some deference to legislative judgments. For example, the Court refused to consider whether the amount of the individual contribution limits (set at $\$ 1000$, which is equal to just under $\$ 3300$ in 2004 dollars $^{30}$ ) was too low. ${ }^{31}$ The amount of contribution limitations would raise constitutional problems only when it prevented candidates and committees from "amassing the resources necessary for effective advocacy." ${ }^{32}$ But the overall tenor and tone of Buckley was one of skepticism of legislative judgments about the need for campaign finance regulation.

${ }^{26} I d$. at 26 .

${ }^{27} I d$. at $46-47$.

${ }^{28} I d$. at 48.

${ }^{29} I d$. at 48-49. Seven of the eight Justices deciding the case concurred in this statement (Justice Stevens, new to the Court, did not participate), though the drafting history reveals that at least two more of the Justices were ambivalent about the equality rationale. See HASEN, Supreme Court \& Election LAW, supra note 13, at 106-07 (noting that during the drafting process, Justices White, Marshall, and Brennan all expressed a willingness to defer to Congress).

${ }^{30}$ Calculated using the "inflation calculator" at the website of the U.S. Department of Labor, Bureau of Labor Statistics: http://data.bls.gov/cgi-bin/cpicalc.pl (last visited September 15, 2004).

${ }_{31}$ Buckley, 424 U.S. at 30 . The Court also upheld an aggregate annual $\$ 25,000$ individual contribution limit to federal candidates, parties, and political committees. Id. at 38; see also Cal. Med. Ass'n v. FEC, 453 U.S. 182 (1981) (CMA) (upholding a \$5000 limit on annual contributions by individuals and unincorporated associations to multicandidate political committees supporting federal candidates). For a further discussion of this aspect of Buckley and CMA, see infra Part IV.C.

${ }^{32}$ Buckley, 424 U.S. at 21. 
Thus, the Court rejected expenditure limits not only because they interfered with free speech and association rights but also becausegiven the Court's narrowing interpretation of FECA's reach only to cover advertisements containing express words of advocacy (such as "Vote for Smith") — the limits could be circumvented easily, meaning that such limits would serve "no substantial societal interest." ${ }^{34}$ Indeed, the Court applied its narrowing construction to FECA's disclosure rules, ${ }^{35}$ leaving many election-related campaign expenditures lacking any regulation whatsoever.

While we may debate in hindsight whether Buckley struck more of a tone of deference or skepticism, there is little doubt that the immediate post-Buckley Supreme Court jurisprudence came down firmly on the side of skepticism. In First National Bank of Boston v. Bellotti, ${ }^{36}$ the Court rejected a Massachusetts law aimed at limiting the participation of corporations in ballot measure campaigns. Defending the law, the state argued that corporate participation in the referendum process would exert undue influence on the outcome of the vote "and-in the end-destroy the confidence of the people in the democratic process and the integrity of government. According to [the state], corporations are wealthy and powerful and their views may drown out other points of view." ${ }^{37}$ Noting that "the proper question ... is not whether corporations 'have' First Amendment rights ... [but whether the Massachusetts law] abridges expression that the First Amendment was meant to protect," 38 the Court held that "the fact that advocacy may persuade the electorate is hardly a reason to suppress it." ${ }^{39}$

Similarly, in Citizens Against Rent Control v. City of Berkeley (CARC) ${ }^{40}$ the Court rejected a city ordinance limiting contributions to ballot measure committees to $\$ 250$. The California Supreme Court had upheld the measure as a means of preserving "voters' confidence" in the ballot measure process, but the United States Supreme Court, in rejecting the ordinance, flatly stated that "the record in this case [did]

\footnotetext{
${ }^{33}$ See id. at 44 n.52 (restricting the application of 18 U.S.C. $\$ 608$ (e) (1) "to communications containing express words of advocacy of election or defeat, such as 'vote for,' 'elect,' 'support,' 'cast your ballot for,' 'Smith for Congress,' 'vote against,' 'defeat,' 'reject.'”).

${ }^{34} I d$. at 45 .

${ }^{35} I d$. at 67.

${ }^{36} 435$ U.S. 765 (1978).

${ }^{37}$ Id. at 789.

${ }^{38} I d$. at 776 .

${ }^{39} I d$. at 790 .

${ }^{40} 454$ U.S. 290 (1981).
} 
not support" the lower court's conclusion that the ordinance was necessary to preserve such voter confidence. ${ }^{41}$ The Court did not explain what evidence would be sufficient to make such a showing.

And in FEC $v$. National Conservative Political Action Committee $(N C P A C),{ }^{42}$ the Court rejected a portion of the Presidential Election Campaign Fund Act that prevented independent spending over $\$ 1000$ to further the election of a presidential candidate who had opted-in to the public financing system. In holding that the law could not be justified on anticorruption grounds, the Court defined corruption as follows:

Corruption is a subversion of the political process. Elected officials are influenced to act contrary to their obligations of office by the prospect of financial gain to themselves or infusions of money into their campaigns. The hallmark of corruption is the financial quid pro quo: dollars for political favors.

Without elaboration, the majority stated that it would defer to the lower court's finding that the evidence of corruption or its appearance supporting the challenged law was "evanescent."

The one exception to the Court's skepticism in the 1980s to campaign finance regulation was for limits on corporate involvement in the political process. Thus, in FEC v. National Right to Work Committee $(N R W C),{ }^{45}$ the Court upheld a federal law that prohibited corporations without shareholders from soliciting anyone but their "members" for their separate political committees. It accepted the government's rationale that the law "ensure[d] that substantial aggregations of wealth amassed by the special advantages which go with the corporate form of organization should not be converted into political 'war chests' which could be used to incur political debts from legislators who are aided by the contributions." ${ }^{46}$ And it held that this rationale could apply even to an ideological organization that had adopted the corporate form. ${ }^{47}$

But even the Court's special solicitude for campaign finance laws regulating corporations was limited: in FEC v. Massachusetts Citizens for

${ }^{41}$ Id. at 299 (citing Citizens Against Rent Control v. City of Berkeley, 614 P.2d 742 (Cal. 1980).

${ }^{42} 470$ U.S. 480 (1985).

43 Id. at 497.

${ }^{4} I d$. at 499.

45459 U.S. 197 (1982).

${ }^{46} I d$. at 207.

${ }^{47} I d$. at 205. 
Life, Inc. (MCFL), the Court held that it violated the First Amendment to apply the FECA provision requiring corporations to fund express advocacy for or against federal candidates only out of separate funds to an ideological corporation that did not engage in business activities, had no shareholders, and was neither established nor would take contributions from a business corporation or labor union. ${ }^{48}$

\section{B. The Austin Interlude}

Recall that the Court in $N R W C$ justified its law based upon the "substantial aggregations of wealth" accomplished with the corporate form that could be used to build "war chests" and incur "political debts," ${ }^{49}$ a classic anticorruption rationale. In MCFL, the Court in dicta transformed that $N R W C$ anticorruption language into what I have termed a "barometer equality" argument, ${ }^{50}$ suggesting that corporate spending might be limited because " $[\mathrm{r}]$ elative availability of funds is after all a rough barometer of public support."

In 1990, the dictum became a holding in Austin v. Michigan Chamber of Commerce. ${ }^{52}$ At issue was a Michigan law that barred corporations, other than media corporations, from using general treasury funds for independent expenditures in state election campaigns. Under the reasoning of Buckley, the law regulating independent expenditures should have been struck down, at least absent proof that corporate independent expenditures in fact allowed for quid pro quo corruption. Instead, the Court accepted the barometer equality rationale for the regulation (at least as applied to corporations), while using the incorrect label of corruption:

Regardless of whether [the] danger of "financial quid pro quo" corruption may be sufficient to justify a restriction on independent expenditures, Michigan's regulation aims at a different type of corruption in the political arena: the corrosive and distorting effects of immense aggregations of wealth that are accumulated with the help of the corporate form and that have little or no correlation to the public's support for the corporation's political ideas.

${ }^{48} 479$ U.S. 238, 263-64 (1986).

499 U.S. at 207.

50 HASEN, SUPREME COURT \& ElECTION LAW, supra note 13, at 110.

${ }^{51}$ MCFL, 479 U.S. 197, 258 (1982).

${ }^{52} 494$ U.S. 652 (1990).

${ }^{53}$ Id. at 659-60 (citations omitted). 
Austin marked the first and only time to that point that the Court had upheld an expenditure limitation, and, as the 1990s progressed, it was unclear whether Austin retained any vitality. ${ }^{54}$ The 1996 case, Colorado I, produced no majority opinion and a plurality opinion from Justices Breyer, O'Connor and Souter that tried to decide as little as possible. The dramatic shift began in 2000 , when it appears that Justices Breyer and Souter got their sea legs on the campaign finance issue.

\section{The Shift in the 2000s: The Deferential Model of Campaign Finance Jurisprudence}

It is wrong to view McConnell as an isolated earthquake in campaign finance jurisprudence. Rather, it is best seen as the latest in a series of significant tremors commencing in 2000 in Nixon v. Shrink Missouri Government PAC, ${ }^{55}$ and continuing in 2001's Colorado $I I^{56}$ and 2003's FEC v. Beaumont. ${ }^{57}$ Justice Souter wrote the majority opinion in all three cases.

In upholding the constitutionality of Missouri's low campaign contribution limits for state offices, the Court majority in Shrink Missouri did four things of jurisprudential significance. ${ }^{58}$ First, the Court ratcheted down the level of scrutiny from Buckley's "exacting" level of

\footnotetext{
${ }^{54}$ See, e.g., Daniel Hays Lowenstein, A Patternless Mosaic: Campaign Finance and the First Amendment After Austin, 21 CAP. U. L. REV. 381, 383 (1992) (suggesting that Austin might be an "aberration").

55 528 U.S. 377 (2000).

${ }^{56} 533$ U.S. 431 (2001).

57539 U.S. 146 (2003). Writing after Beaumont but before McConnell, Brad Smith already saw the trend developing. See Bradley A. Smith, Campaign Finance Reform: Searching for Corruption in All the Wrong Places, 2002-2003 CATO SUP. CT. REV. 187, 222 ("Beaumont on its own is not particularly significant, but combined with other recent cases, most notably Shrink PAC and Colorado Republican II, it is significant indeed."); see also Fredric D. Woocher, Beaumont v. Federal Election Commission: A Pre-Cursor of More Important Things to Come?, 2 ELECTION L.J. 255, 260-61 (2003) ("[T]hose interested in the fate of the BCRA would be well-advised to pay heed to the Supreme Court's decision in Beaumont.").

${ }^{58}$ I provide greater detail on these claims in Richard L. Hasen, Shrink Missouri, Campaign Finance, and "The Thing that Wouldn't Leave," 17 CONST. COMMENT. 483, 49097 (2000).
} 
scrutiny ${ }^{59}$ to one in which interests need only be "sufficiently important" ${ }^{\prime 60}$ and not narrowly tailored to the government's interest. ${ }^{61}$

Second the Court sufficiently expanded the definitions of "corruption" and "the appearance of corruption" to justify campaign finance regulation. The Court explained that "corruption" extended beyond quid pro quo arrangements to embrace "the broader threat from politicians too compliant with the wishes of large contributors." ${ }^{62}$ As for "the appearance of corruption," the Court remarked, "[1] eave the perception of impropriety unanswered, and the cynical assumption that large donors call the tune could jeopardize the willingness of voters to take part in democratic governance." ${ }^{33}$

Third, and perhaps most significantly, the Court lowered the evidentiary burden for proving corruption or its appearance. The Court began by noting that " $[\mathrm{t}]$ he quantum of empirical evidence needed to satisfy heightened judicial scrutiny of legislative judgments will vary up or down with the novelty and plausibility of the justification raised." ${ }^{64}$ Although the Court insisted that "mere conjecture" ${ }^{65}$ was not enough to support a campaign limit, it held that Missouri could justify the need for its contribution limits to fight corruption or the appearance of corruption by relying on some pretty flimsy evidence: an affidavit from a Missouri legislator who had supported the legislation stating that large contributions have "the real potential to buy votes"; ${ }^{66}$ newspaper accounts suggesting possible corruption in Missouri politics; ${ }^{67}$ and the passage of an earlier Missouri voter initiative establishing campaign contribution limits. ${ }^{68}$

Fourth, the Court created a difficult test for challenging the constitutionality of a contribution limit as too low to prevent effective advocacy. Refining (or changing) the effective advocacy test from Buck-

\footnotetext{
${ }^{59}$ See Buckley v. Valeo, 424 U.S. 1, 16 (1976) (per curiam) (“[T]his Court has never suggested that the dependence of a communication on the expenditure of money operates itself to introduce a nonspeech element or to reduce the exacting scrutiny required by the First Amendment.").

${ }^{60}$ Shrink Missouri, 528 U.S. at 388 (quoting Buckley, 424 U.S. at 25 (citation and internal quotation marks omitted)).

${ }^{61}$ See id. ("[T] he dollar amount of the limit need not be 'fine tun[ed]." (alteration in original, citation omitted)).

${ }^{62} I d$. at 389.

${ }^{63} I d$. at 390

${ }^{64} I d$. at 391 .

${ }^{65}$ Id. at 392.

${ }^{66} I d$. at 393 (quoting an affidavit from State Senator Wayne Goode).

${ }^{67} I d$.

${ }^{68}$ Id. at 394.
} 
ley, the Court stated: "[w]e asked, in other words, whether the contribution limitation was so radical in effect as to render political association ineffective, drive the sound of a candidate's voice below the level of notice, and render contributions pointless. ${ }^{, 69}$ In an era of faxes, web pages, and e-mails, it is hard to imagine any contribution limit that would fail the test of constitutionality.

Shrink Missouri was also the case where Justice Breyer, in a concurring opinion, fired his opening salvo for the participatory selfgovernment rationale. Remarking that Buckley's statement rejecting the equality rationale as being wholly foreign to the First Amendment "cannot be taken literally," J0 Justice Breyer posited that "constitutionally protected interests lie on both sides of the legal equation." ${ }^{71} \mathrm{He}$ explained:

On the one hand, a decision to contribute money to a campaign is a matter of First Amendment concern-not because money is speech (it is not); but because it enables speech. ...

On the other hand, restrictions upon the amount any one individual can contribute to a particular candidate seek to protect the integrity of the electoral process-the means through which a free society democratically translates political speech into concrete governmental action. Moreover, by limiting the size of the largest contributions, such restrictions aim to democratize the influence that money itself may bring to bear upon the electoral process. In doing so, they seek to build public confidence in that process and broaden the base of a candidate's meaningful financial support, encouraging the public participation and open discussion that the First Amendment itself presupposes.

Justice Breyer then called for deference to the legislature's understanding of "the threat to electoral integrity [and] the need for democratization," ${ }^{73}$ though not for deference with respect to whether a contribution limit "significantly increases the reputation-related or media-related advantages of incumbency . ...,"74

Colorado II continued the trend toward relaxing Buckley's rules. The question there was whether political parties had a constitutional

${ }^{69} I d$. at 397.

${ }^{70} I d$. at 402 (Breyer, J., concurring).

${ }^{71}$ Id. at 400 .

${ }^{72} I d$. at 400-01 (citations omitted).

73 Id. at 403 .

${ }^{74} I d$. at 404 . On this point, Justice Breyer wrote that the statutory limit was "low enough to raise such a question. But given the empirical information presented ... I agree with the Court that the statute does not work disproportionate harm." Id. 
right to spend unlimited sums in coordination with the parties' candidates. FECA treats a coordinated expenditure as a contribution, and limits the amount of coordinated expenditures that a party may make with a party's candidate. ${ }^{75}$ By a 5-4 vote, the Court upheld the FECA provision, primarily on grounds that parties may serve as conduits for corruption: "[W] hether they like it or not, [parties] act as agents for spending on behalf of those who seek to produce obligated officeholders. ${ }^{, 76}$ In support of this conclusion, the Court once again relied upon some rather casual empirical evidence. ${ }^{77}$

One question left open after $M C F L$ was whether it was permissible for the government to limit campaign contributions by corporations entitled to an MCFL exemption from the ban on direct corporate expenditures. In FEC v. Beaumont, ${ }^{78}$ the Supreme Court held it was permissible to ban such contributions.

Beaumont is significant in two respects. First, the Court called into question Bellotti's statement that the corporate form of the speaker is irrelevant for purposes of determining the degree of First Amendment protection. Thus, the Beaumont Court declared:

Within the realm of contributions generally, corporate contributions are furthest from the core of political expression, since corporations' First Amendment speech and association interests are derived largely from those of their members, and of the public in receiving information. A ban on direct corporate contributions leaves individual members of corporations free to make their own contributions, and deprives the public of little or no material information. ${ }^{79}$

Following Beaumont, it became an open question whether a ban on corporate expenditures, even in the context of ballot measure cam-

\footnotetext{
${ }^{75}$ See 2 U.S.C. $\$ 441 \mathrm{a}(\mathrm{a})(7)$ (B) (i) ("For purposes of this subsection ... expenditures made by any person in cooperation, consultation, or concert, with, or at the request or suggestion of, a candidate, his authorized political committees, or their agents, shall be considered to be a contribution to such candidate."); 2 U.S.C. § $441 \mathrm{a}(\mathrm{d})$ (3) ("The national committee of a political party, or a State committee of a political party, including any subordinate committee of a State committee, may not make any expenditure in connection with the general election campaign of a candidate for Federal office in a State who is affiliated with such party which exceeds [specified limits].")

${ }^{76}$ Colorado II, 533 U.S. at 452.

${ }^{77}$ See Richard L. Hasen, The Constitutionality of a Soft Money Ban After Colorado Republican II, 1 ELECTION L.J. 195, 203 (2002) (explaining that the Court did its own research by "web-surfing to the FEC's website to look at the pattern of PAC giving to candidates").

${ }^{78} 539$ U.S. 146 (2003).

${ }^{79} I d$. at 161 n.8 (citations omitted).
} 
paigns, might also be said to "leave individual members of corporations free to make their own... [expenditures] and deprive[] the public of little or no material information."”o

Second, Beaumont suggested that Austin remained good law, though without quoting Austin's most controversial language endorsing the barometer equality rationale. ${ }^{81}$ The Beaumont Court further bolstered its analysis by applying Colorado II's anticircumvention rationale to the case of corporate contributions, ${ }^{82}$ and noting that judicial deference was particularly appropriate "where, as here, we deal with a congressional judgment that has remained essentially unchanged throughout a century of "careful legislative adjustment."

What remained of Buckley after the three post-2000 decisions was principally its rule against campaign expenditure limits outside the context of corporate (and perhaps union) expenditures. McConnell built upon the other three post-2000 decisions and, as the next two Parts show, it calls into question even the contribution-expenditure dichotomy. Buckley appears to be dying a slow death beneath the rubble created by recent seismic events.

\section{MCCONNELL V. FEDERAL ELECTION COMMISSION: FIDELITY TO THE NEW POST-2000 JURISPRUDENCE}

\section{A. The Basic Soft Money and Issue Advocacy Holdings of McConnell}

Although the Court decided challenges to over twenty provisions of BCRA, I focus here on the Court's decision to uphold BCRA's various soft money provisions, ${ }^{84}$ as well as the Court's decision upholding

${ }^{80}$ LOWENSTEIN \& HASEN, supra note 7, at 855 (quoting Beaumont, 539 U.S. at 161 n.8).

${ }^{81}$ See Beaumont, 539 U.S. at 153-54 (citing Austin for its anticorruption rationale).

${ }^{82}$ See id. at 155 (" $[\mathrm{R}]$ estricting contributions by various organizations hedges against their use as conduits for 'circumvention of [valid] contribution limits.'”) (quoting Colorado II, 533 U.S. at $456 \mathrm{n} .18$ (alteration in original)).

${ }^{83}$ Id. at 162 n.9 (quoting NRWC, 459 U.S. 197, 209 (1982)).

${ }^{84}$ The joint majority opinion in McConnell gave this history of the rise of soft money:

$[\mathrm{P}]$ rior to the enactment of BCRA, federal law permitted corporations and unions, as well as individuals who had already made the maximum permissible contributions to federal candidates, to contribute "nonfederal money"-also known as "soft money"- to political parties for activities intended to influence state or local elections.

Shortly after Buckley was decided, questions arose concerning the treatment of contributions intended to influence both federal and state elections. $\mathrm{Al}$ though a literal reading of FECA's definition of "contribution" would have re- 
a BCRA provision preventing corporations and labor unions from spending funds on "electioneering communications" except through a segregated fund. The joint majority opinion of Justices Stevens and O'Connor addressed the constitutionality of these provisions.

The Court upheld all of the soft money provisions of BCRA. Thus, the Court held that it was permissible for Congress to (1) prohibit national party committees and their agents from soliciting, receiving, or spending any soft money $(\S 323(\mathrm{a})) ;^{85}$ (2) prevent donors from contributing nonfederal funds to state and local party committees to help finance "federal election activity" $(\S 323(\mathrm{~b})) ;^{86}$ (3) prohibit national, state, and local party committees, and their agents or subsidiaries, from soliciting any funds for, or making or directing any donations to, certain tax-exempt organizations that make expenditures in connection with elections for federal office $(\S 323(\mathrm{~d})) ;{ }^{87}(4)$ prohibit federal candidates and officeholders from soliciting, receiving, directing, transferring or spending soft money in connection with federal elections, and limiting the ability of federal candidates and officeholders to solicit, receive, direct, transfer, or spend soft money in connection with state and local elections $(\S 323(\mathrm{e})) ;^{88}$ and (5) pro-

quired such activities to be funded with hard money, the FEC ruled that political parties could fund mixed-purpose activities-including get-out-the-vote drives and generic party advertising - in part with soft money. In 1995 the FEC concluded that the parties could also use soft money to defray the costs of "legislative advocacy media advertisements," even if the ads mentioned the name of a federal candidate, so long as they did not expressly advocate the candidate's election or defeat.

124 S. Ct. at $648-49$.

${ }^{85}$ See id. at 659-70 (upholding 2 U.S.C. $§ 441 i(a)$ (new FECA $\$ 323(a)$ ).

${ }^{86}$ See id. at 670-77 (upholding 2 U.S.C. § 441i(b) (1) (new FECA § 323(b)). BCRA defined "federal election activity" to include (1) voter registration efforts during the 120 days before a regularly scheduled federal election; (2) voter identification, get-outthe-vote and generic campaign activity that is "conducted in connection with an election in which a candidate for Federal office appears on the ballot;" (3) any "public communication that refers to a clearly identified candidate for Federal office" and "promotes," "supports," "attacks," or "opposes" "a candidate for that office;" and (4) the services provided by a state committee employee who devotes more than 25 percent of his or her time to activities in connection with a federal election. 2 U.S.C. $\$ \S$ 431(20) (A) (i)-(iv). The provision provided an exception, the "Levin Amendment," allowing state and local parties to pay for some of this activity partly with contributions limited to $\$ 10,000$ per person. Such funds could not be used to pay for any activities that refer to a clearly identified candidate for federal office and they could not be used to fund broadcast communications unless they referred solely to a clearly identified candidate for state or local office. 2 U.S.C. $\$ 441$ i(b) (2) (B) (i)-(ii).

${ }^{87}$ McConnell, 124 S. Ct. at 678-82 (upholding 2 U.S.C. $\S 441$ (d) (new FECA $\S$ $323(d))$

${ }_{88} I d$. at 682-83 (upholding 2 U.S.C. $§ 441$ i(e) (new FECA $§ 323(\mathrm{e})$ ). 
hibit state or local officeholders and candidates from spending soft money to fund communications that refer to a clearly identified candidate for federal office and that promote, support, attack or oppose a candidate for that office $(\S 323(\mathrm{f})){ }^{89}$

As for issue advocacy, the Court upheld Congress's extension of the existing requirement-that corporations and labor unions use separate funds for express advocacy-to the funding of broadcast communications that refer to clearly identified candidates for federal office, made within sixty days of a general election or thirty days of a primary, and targeted at the relevant electorate where the candidate is running for office $(\S 203) .^{90}$

No doubt, some of these provisions could have been upheld as a straightforward application of Buckley. For example, even Justice Kennedy, who dissented from virtually all of the joint majority opinion, voted to uphold $\S 323(\mathrm{e})$, the ban on solicitation of soft money by federal officeholders and candidates: "The making of a solicited gift is a quid both to the recipient of the money and to the one who solicits the payment (by granting his request). ${ }^{91}$ But a number of these provisions required the Court to go well beyond Buckley.

\section{B. Fidelity to Buckley or Fidelity to Shrink Missouri?}

Here, I offer three examples to demonstrate that the joint majority opinion in McConnell fits much more comfortably with the three other post-2000 campaign finance decisions than with Buckley.

1. Regulating Activities of Local Political Parties and Candidates

The joint majority opinion cited some pretty compelling evidence that the national political parties had become conduits for the sale of access to federal candidates and officeholders. Assuming for now that

\footnotetext{
${ }^{89} I d$. at 683-84 (upholding 2 U.S.C. $§ 441 \mathrm{i}(\mathrm{f})$ (1) (new FECA $§ 323(\mathrm{f})$ ). The law provided some exemptions when the federal officeholder was running for state or local office. 2 U.S.C. $\$ 441$ (f) (2).

${ }^{90}$ See McConnell, 124 S. Ct. at 694-98 (upholding 2 U.S.C. $\$ 441 b(b)(2)$ ); 2 U.S.C. $\S 434$ (f) (3) (A) (i) (new BCRA $\S 201$ ) (defining "electioneering communication"). The Court, by an 8-1 vote, also upheld the disclosure rules using the new definition of electioneering communications. McConnell, 124 S. Ct. at 689-94; see Hasen, supra note 12 (discussing McConnell's disclosure analysis).

${ }^{91}$ McConnell, 124 S. Ct. at 754 (Kennedy, J., dissenting). Chief Justice Rehnquist joined Justice Kennedy on this point.
} 
the sale of access constitutes corruption, ${ }^{92}$ or at least creates the appearance of corruption, the Court appeared on solid ground under Buckley in upholding the national party soft money ban. ${ }^{93}$ The Court also cited some evidence of a danger that state political parties could become new conduits for the sale of access to federal officeholders. ${ }^{94}$

But there was no evidence of the potential for the sale of access through local political parties and plenty of evidence that BCRA's soft money restrictions could interfere with the purely local electionrelated activities. In upholding the constitutionality of BCRA section 323(b), the joint majority opinion cited to the deposition of a single former senator, stating that "much of what state and local parties do helps to elect federal candidates, ${ }^{, 95}$ as well as to other depositions showing that national party officials had directed maxed-out national party donors to the state parties:

[I]n addressing the problem of soft-money contributions to state committees, Congress both drew a conclusion and made a prediction. Its conclusion, based on the evidence before it, was that the corrupting influence of soft money does not insinuate itself into the political process solely through national party committees. Rather, state committees function as an alternate avenue for precisely the same corrupting forces. Indeed, both candidates and parties already ask donors who have reached the limit on their direct contributions to donate to state committees. There is at least as much evidence as there was in Buckley that such donations have been made with the intent-and in at least some cases the effect-of gaining influence over federal officeholders. Section 323(b) thus promotes an important governmental interest by confronting the corrupting influence that soft-money donations to political parties already have.

Congress also made a prediction. Having been taught the hard lesson of circumvention by the entire history of campaign finance regulation, Congress knew that soft-money donors would react to $\S 323$ (a) by scrambling to find another way to purchase influence. It was "neither novel nor implausible" for Congress to conclude that political committees would react to $\S 323$ (a) by directing soft-money contributors to the state committees, and that federal candidates would be just as indebted to these contributors as they had been to those who had formerly con-

${ }^{92}$ But see McConnell, 124 S. Ct. at 750 (Kennedy, J., dissenting) (“As a conceptual matter, generic party contributions may engender good will from a candidate or officeholder.... Still, no Member of Congress testified this favoritism changed voting behavior."). I return to the issue of access as corruption in Part IV, infra.

${ }^{93}$ See id. at 659-70 (discussing the constitutionality of new FECA $§ 323(\mathrm{a})$ ).

${ }^{94} I d$. at $672-73$.

${ }^{95}$ Id. at 672 n.59 (quoting McConnell v. FEC, 251 F. Supp. 2d 176, 467 (D.D.C. 2003) (Kollar-Kotelly, J.) (quoting former Senator Rudman)). 
tributed to the national parties. We "must accord substantial deference to the predictive judgments of Congress," particularly when, as here, those predictions are so firmly rooted in relevant history and common sense. Preventing corrupting activity from shifting wholesale to state committees and thereby eviscerating FECA clearly qualifies as an important governmental interest. ${ }^{96}$

Note the absence of evidence that local parties had been used in the past to circumvent federal contribution limits or to gain access to federal officeholders. As the Chief Justice remarked in dissent: "I am unaware of any evidence in the record that indicates that local political parties have any relationship with federal candidates. ${ }^{, 97}$ The local party ban therefore depended not on any evidence of corruption (or even the sale of access) but on a supposition that local parties have the potential to corrupt federal officeholders through the sale of access based on the benefits they may provide to federal candidates. ${ }^{98}$

The Court held that:

[The] argument, that soft-money contributions to state and local candidates for "public communications" do not corrupt or appear to corrupt federal candidates, ignores both the record in this litigation and Congress' strong interest in preventing circumvention of otherwise valid contribution limits.... We will not upset Congress' eminently reasonable prediction that, with these other avenues no longer available, state and local candidates and officeholders will become the next conduits for the soft-money funding of sham issue advertising. ${ }^{99}$

Potential benefits turn out to be the key to the joint majority opinion's upholding of a number of BCRA's more controversial provisions. Thus, the Court upheld BCRA section 323(f)'s requirement that state

${ }^{96} I d$. at 672-73 (citations and footnotes omitted).

${ }_{97} I d$. at 780 n.3 (Rehnquist, C.J., dissenting).

${ }^{98}$ The Court also upheld application of the section 323(a) soft money ban to minor parties, in the absence of any evidence that the ban would prevent corruption or its appearance. $I d$. at 669 (suggesting that a "nascent or struggling minor party" bring an as-applied challenge if the ban prevented amassing the resources necessary for effective advocacy). An as-applied challenge would be very difficult to meet under Shrink Missouri's standard for proving that a law prevents amassing resources necessary for effective advocacy. See supra text accompanying note 69 (examining the standard in Shrink Missouri). Indeed, in rejecting the argument that section 323(b) prevented state and local parties from amassing the resources necessary for effective advocacy, the joint majority opinion confirmed that, in bringing an as-applied challenge, " $[\mathrm{t}] \mathrm{he}$ question is not whether $\S 323$ (b) reduces the amount of funds available over previous election cycles, but whether it is 'so radical in effect as to ... drive the sound of [the recipient's] voice below the level of notice." McConnell, 124 S. Ct. at 677 (quoting Shrink Missouri, 528 U.S. at 397 (alterations in original)).

${ }^{99}$ McConnell, 124 S. Ct. at 684. 
and local officeholders or candidates use only hard (federal) money to pay for any public communication that refers to a federal candidate and that promotes, supports, attacks, or opposes such a candidate (such as a local candidate who wishes to send a mailing in 2004 "urging voters to nominate Republicans like himself who support President Bush's policies"). ${ }^{100}$ "We will not upset Congress' eminently reasonable prediction that ... state and local candidates ... will become the next conduits for the soft-money funding of sham issue advertising." ${ }^{101}$ Similarly, the Court upheld a ban on national party officials' soliciting of soft money for tax-exempt organizations engaged in political activity on the same basis: "Absent the solicitation provision, national, state, and local party committees would have significant incentives to mobilize their formidable fundraising apparatuses, including the peddling of access to federal officeholders, into the service of like-minded tax-exempt organizations that conduct activities benefiting their candidates."

The theory that local political parties, local officials, or non-profit political organizations may become the next conduits for the sale of access certainly is "plausible," and under Shrink Missouri plausibility is enough for constitutional regulation. ${ }^{103}$ The problem with a plausibility standard is the lack of a principled stopping point for legislative reach. As the Chief Justice remarked:

Newspaper editorials and political talk shows benefit federal candidates and officeholders every bit as much as a generic voter registration drive conducted by a state party; there is little doubt that the endorsement of a major newspaper affects federal elections, and federal candidates and officeholders are surely "grateful" for positive media coverage. I doubt, however, the Court would seriously contend that we must defer to Congress' judgment if it chose to reduce the influence of political endorsements in federal elections. ${ }^{104}$

${ }^{100}$ Lowenstein, supra note 15, at 281; see also McConnell, 124 S. Ct. at 683-84 ("Section 323(f) generally prohibits candidates for state or local office ... from spending soft money to fund ... a communication that refers to a clearly identified candidate for Federal office ... and that promotes or supports a candidate for that office, or attacks or oppose a candidate for that office.").

${ }^{101}$ McConnell, 124 S. Ct. at 684.

${ }^{102} I d$. at 678.

${ }^{103}$ See Shrink Missouri, 528 U.S. at 378 ("The quantum of empirical evidence needed to satisfy heightened judicial scrutiny of legislative judgments will vary up or down with the novelty and plausibility of the justification raised.")

${ }^{104}$ McConnell, 124 S. Ct. at 780 (Rehnquist, C.J., dissenting) (citations omitted). 
The joint majority opinion's answer to the Chief Justice on this point was unsatisfying, expressing agreement without any explanation that Congress could not regulate "financial contributions" to political talk show hosts or newspaper editors "on the sole basis that their activities conferred a benefit on the candidate," and noting, without citing any further evidence, that "[t] he close relationship" between candidates and their parties "makes state and local parties effective conduits for donors desiring to corrupt federal candidates and officeholders. ${ }^{.105}$

Given that most political talk show hosts or newspaper editors would not be accepting financial contributions, the majority's response was somewhat off-the-mark. The Chief Justice's point was not so much about contributions to such persons but rather to the possibility that Congress could limit their election-related activities on grounds that the activities benefit candidates and affect federal elections.

In any event, the Court's analysis on the local party and candidate issue is clearly in line with post-2000 jurisprudence. Lacking reasonable evidence of actual corruption or the appearance of corruption, the Court, as in Colorado II, shifted to the mere possibility of circumvention and then used Shrink Missouri's lowering of the evidentiary bar: once the Court declared a claim of potential corruption "neither novel nor implausible," it was poised to uphold the provision. ${ }^{106}$ The joint majority opinion's analysis of the issue ended, consistently with Shrink Missouri, Colorado II, and Beaumont, with a call for deference to Congress. $^{107}$

\section{Shallow Overbreadth Analysis on the Issue Advocacy Provisions}

Before the Supreme Court decided McConnell, many people believed that the question of whether the Court would uphold BCRA section 203's extension of the separate fund requirement for corporations and labor unions depended upon the extent to which the law's bright-line test for electioneering communications would capture

${ }^{105}$ Id. at $668 \mathrm{n} .51$; see also id. at 666 ("To be sure, mere political favoritism or opportunity for influence alone is insufficient to justify regulation.”).

106 Id. at 661.

${ }^{107}$ See id. at 706 ("Many years ago we observed that to say that Congress is without power to pass appropriate legislation to safeguard ... an election from the improper use of money to influence the result is to deny to the nation. . . the power of self protection. We abide by that conviction [today].... (citation, internal quotation marks, and brackets omitted)). 
"genuine issue ads," that is, advertisements not intended to influence the outcome of federal elections, such as advertisements run just before a presidential election by a corporation or union asking the president to get involved in a nasty labor dispute. " Few advertisements featuring express words of advocacy, such as "Vote for Smith," would not be election-related. On the other hand, it was unclear how many advertisements referring to a federal candidate in the sixty days before an election would be election-related. To the extent that such advertisements were not election-related, the law might have been substantially overbroad-capturing too much speech that Congress would have insufficient reason to regulate-and therefore in violation of the First Amendment. ${ }^{109}$

The three lower court judges hearing McConnell devoted many pages and considerable effort to this question and focused particularly on two social science studies (the "Buying Time" studies ${ }^{110}$ ) examining the question. ${ }^{111}$ Judge Leon found that between $14.7 \%$ and $17 \%$ of the ads run before the 1998 and 2000 elections were genuine issue advertisements. ${ }^{112}$ Judge Kollar-Kotelly disagreed with both the $17 \%$ figure as well as its significance for the overbreadth analysis. ${ }^{113}$ Judge Henderson believed the figure was anywhere from $11.38 \%$ to $50.5 \%$ and, in any case, that the law was overbroad. ${ }^{114}$ The social science con-

${ }^{108}$ See, e.g., Richard L. Hasen, Measuring Overbreadth: Using Empirical Evidence to Determine the Constitutionality of Campaign Finance Laws Targeting Sham Issue Advocacy, 85 MINN. L. REV. 1773, 1797 (2001) (arguing that whether bright-line tests are constitutionally overbroad depends on the frequency with which they capture speech not intended to influence the outcome of an election).

${ }^{109}$ See Broadrick v. Oklahoma, 413 U.S. 601, 615 (1973) ("[W]e believe that the overbreadth of a statute must not only be real, but substantial as well, judged in relation to the statute's plainly legitimate sweep."). For my own look at the empirical evidence of the potential for overbreadth with a BCRA-like bright line test, see Hasen, supra note 108, at 1797 (2001).

${ }^{110}$ Craig B. Holman \& Luke P. Mcloughlin, Brennan Ctr. For Justice, BuYING TIME 2000: TELEVISION ADVERTISEMENTS IN THE 2000 FEDERAL ElECTIONS (2001); Jonathan S. Krasno \& Daniel E. Seltz, Brennan Ctr. For Justice, Buying Time 1998: TELEVISION ADVERTISING IN THE 1998 CONGRESSIONAL ELECTIONS (2000).

${ }^{111}$ McConnell v. FEC, 251 F. Supp. 2d 176, 367-73 (D.D.C.) (Henderson, J., concurring in part and dissenting in part), aff'd in part and rev'd in part, 124 S. Ct. 619 (2003); id. at 610-39, 719-52 (Kollar-Kotelly, J., concurring); id. at 792-99, 890-918 (Leon, J., concurring).

${ }^{112} I d$. at 795-99 (Leon, J., concurring).

${ }^{113}$ Id. at 636 (Kollar-Kotelly, J., concurring).

${ }^{114} I d$. at 372 n.149 (Henderson, J., concurring in part and dissenting in part). 
troversy spilled into the popular press after the lower court opinions issued. ${ }^{115}$

It was therefore surprising that the Supreme Court majority opinion devoted only a single paragraph to this issue. On the main point, the Court wrote:

The precise percentage of issue ads that clearly identified a candidate and were aired during those relatively brief preelection time spans but had no electioneering purpose is a matter of dispute between the parties and among the judges on the District Court. Nevertheless, the vast majority of ads clearly had such a purpose. ${ }^{116}$

The joint majority opinion cited to those pages in Judge Leon's opinion containing factual findings noting that " $[\mathrm{m}]$ any so-called 'issue ads' by political parties were actually electioneering advertisements that focused" either on the positions, past actions, or general character traits of federal candidates, or compared the position of two competing federal candidates, but not upon upcoming federal executive action or pending legislation. ${ }^{117}$ The Court neither cited to nor refuted Judge Leon's conclusion that up to 17 percent of advertisements could be considered "genuine issue advertisements," $" 118$ nor did it explain how such a number could be consistent with the Court's determination that a "vast majority" of such ads had an electioneering purpose.

After concluding that the vast majority of advertisements featuring candidates for federal office had an electioneering purpose, the Court added: "Moreover, whatever the precise percentage may have been in the past, in the future corporations and unions may finance genuine issue ads during those time frames by simply avoiding any specific reference to federal candidates, or in doubtful cases by paying for the ad from a segregated fund." 119 The Court's solution to overbreadth thus

${ }^{115}$ Compare George F. Will, 1,600 Pages of Confusion, WASH. POST, May 8, 2003, at A31 (discussing the "sham 'social science"" that "powerfully influenced the congressional vote on McCain-Feingold and is the foundation of two of the three judges' opinions that much of McCain-Feingold is constitutional"), with Thomas E. Mann, No Merit in Brennan Center Smear Campaign, Roll CALL, May 22, 2003, at http://www.brook.edu/views/articles/mann/20030522.htm (asserting that the central conclusions of the Buying Time studies are valid regardless of the McCain-Feingold opponents' critique of their methodology).

${ }^{116}$ McConnell, 124 S. Ct. at 696 (citations omitted).

${ }^{117}$ McConnell, 251 F. Supp. 2d at 826 (Leon, J., concurring in part and dissenting in part).

${ }^{118}$ See id. at 798 (Leon, J., concurring in part and dissenting in part) (discussing Professor Goldstein's testimony).

${ }^{119}$ McConnell, 124 S. Ct. at 696. 
created a potential new First Amendment problem by regulating the content that a corporation or labor union might use to communicate a political message.

Compounding the issue of overbreadth was the Court's treatment of "as applied" challenges, that is, challenges brought by individuals engaging in activity protected by the First Amendment but regulated under an allegedly overly broad law. In a number of places in the joint majority opinion, the Court suggested that some First Amendment challenges to BCRA might come in the form of as-applied challenges after the law was put into operation. ${ }^{120}$ However, it is not clear from the joint majority opinion whether a corporation or labor union (or an entity taking corporate or union funds) that wishes to spend unlimited funds on a "genuine issue advertisement" featuring a candidate for federal office could successfully mount such an as-applied challenge. The Court did write that "we assume that the interests that justify the regulation of campaign speech might not apply to the regulation of genuine issue ads." ${ }^{, 21}$ But in the portion of the majority opinion addressing Title $\mathrm{V}$ of BCRA, the majority characterized its holding on section 203 as "upholding stringent restrictions on all election-time advertising that refers to a candidate because such advertising will often convey message of support or opposition."122 This language, with its original emphasis, suggests that corporations and labor unions may not be successful in making such as-applied challenges; the Court instead appears willing to restrict all election-time advertising that refers to a candidate as such because it will often be constitutionally subject to regulation. ${ }^{123}$

The joint majority opinion's cursory analysis of the overbreadth issue is again consistent with the Court's post-2000 jurisprudence. The Court appeared to care little about the actual evidence, offering instead a conclusory statement that the "vast majority" of the advertise-

${ }^{120}$ See supra note 98 (noting that an "as-applied challenge would be very difficult to meet under Shrink Missouri's standard").

${ }^{121}$ McConnell, 124 S. Ct. at 696 n.88.

${ }^{122}$ Id. at 715 (Breyer, J.).

${ }^{123}$ In Wisconsin Right to Life, Inc. v. FEC, No. 04-1260 (D.D.C. Aug. 17, 2004), available at http://www.fec.gov/pages/bcra/wrtl_opinion.pdf, a district court refused a request for a preliminary injunction by a group bringing such an as-applied challenge. Chief Justice Rehnquist then denied a request for such an injunction pending an appeal. Wis. Right to Life, Inc. v. FEC, No. 04A194, 2004 WL 2086023 (Rehnquist, Circuit Justice, U.S. Sept. 14, 2004). 
ments were sham issue ads, ${ }^{124}$ and deferring to a congressional determination that regulation was necessary.

\section{Regulating Union Expenditures on Electioneering Communications}

The Michigan law at issue in the Austin case prohibited nonmedia corporations, but not labor unions, from making expenditures funding express advocacy. The Austin Court held that the statute was not rendered constitutionally underinclusive by its failure to include labor unions:

Whereas unincorporated unions, and indeed individuals, may be able to amass large treasuries, they do so without the significant state-conferred advantages of the corporate structure; corporations are "by far the most prominent example of entities that enjoy legal advantages enhancing their ability to accumulate wealth.” ...

Moreover, labor unions differ from corporations in that union members who disagree with a union's political activities need not give up full membership in the organization to avoid supporting its political activities. Although a union and an employer may require that all bargaining unit employees become union members,.... [a]n employee who objects to a union's political activities ... can decline to contribute to those activities, while continuing to enjoy the benefits derived from the union's performance of its duties as the exclusive representative of the bargaining unit on labor-management issues. As a result, the funds available for a union's political activities more accurately reflects members' support for the organization's political views than does a corporation's general treasury. ${ }^{125}$

This reasoning not only provided a potentially good reason for a legislature to exclude unions from the corporate segregated fund re-

${ }^{124}$ This problem of the majority ignoring the evidence runs throughout the opinion. Indeed, the majority never mentions the point that, because the lower McConnell Court was a three-judge panel, the Court apparently should have deferred only to the factual findings made by at least a majority of the lower court judges. See Wright v. Rockefeller, 376 U.S. 52, 71 (1964) (Goldberg, J., dissenting) ("In light of these conflicting opinions and analyses, this case cannot be fairly decided on the ground stated in the opinion of the Court, viz., that '[w] e accept the District Court's finding' ... [because] Judges Moore and Feinberg, who comprised the majority below, differed ... with regard to the proof." (first alteration in original)). Instead, the joint majority opinion picks and chooses among the opinions of the lower court judges (primarily Judge Kollar-Kotelly, who would have upheld most of BCRA) for support without ever confronting the evidentiary problem.

${ }^{125}$ Austin v. Mich. State Chamber of Commerce, 494 U.S. 652, 665-66 (1990) (citations omitted). 
quirement, ${ }^{126}$ but also a challenge to anyone who would seek to justify a segregated fund requirement for unions under the Austin rationale.

In McConnell, the Court upheld the extension of the segregated fund requirement to unions' electioneering communications, without ever considering whether the Austin rationale applied. In a single paragraph, the joint majority opinion resolved the issue: it simply cited to Austin, Beaumont, Colorado II, and NRWC on the special need to regulate corporations and the need to prevent circumvention of valid contribution limits, and left it at that. ${ }^{127}$

\section{MCCONNELL AS THE LATEST TRANSITIONAL CASE TOWARD THE PARTICIPATORY SELF-GOVERNMENT RATIONALE}

At least in hindsight, ${ }^{128}$ Shrink Missouri, Colorado II, and Beaumont may well be transitional cases toward the participatory self-government rationale. Neither a substantial danger of corruption nor the appearance of corruption appears to explain a legislative need to enact very low contribution limits, limits on party-coordinated expenditures of hard money on candidates, or a prohibition on campaign contributions to federal candidates by ideological nonprofit corporations. Which candidate for state or federal office would be bought (or even appear to be bought) by a $\$ 1075$ donation, an individual's limited hard money donation made to a political party, or a small contribution from an ideological corporation? Rather, these laws-as read by the Court in the post-2000 cases-reflect a legislative desire to "democratize the influence that money can bring to bear upon the electoral process, thereby building public confidence in that process, broadening the base of a candidate's meaningful financial support, and encouraging greater public participation." ${ }^{129}$

McConnell, too, appears to be a transitional case, with even stronger signals pointing to the participatory self-government rationale. The joint majority opinion no doubt takes pains to show its fidelity to Buckley, tripping over itself to apply the corruption (as anticir-

${ }^{126}$ Justice Scalia suggested a less charitable possibility: the power of Michigan's labor unions over the state legislature. Id. at 692 (Scalia, J., dissenting).

${ }^{127}$ McConnell, 124 S. Ct. at 695-96. The Court's citation to NRWC in support of the barometer equality rationale is curious, given that NRWC did not endorse that rationale.

${ }^{128}$ In 2000, I suggested that Shrink Missouri could play a transitional role away from Buckley. See Hasen, supra note 58, at 505-07 (discussing how each of the Supreme Court Justices would be likely to read Shrink Missouri).

${ }^{129}$ Breyer, supra note 3, at 253. 
cumvention) rationale to as many BCRA provisions as possible. However, a more natural reading of the more controversial aspects of the joint majority opinion is as a sub silentio acceptance of the participatory self-government rationale.

Certainly, the Court's decision to reaffirm Austin and apply it to electioneering communications fits into the participatory selfgovernment rationale. The Court can continue to dress up Austin's barometer equality argument as one based on preventing "corruption," but no one is fooled. The only (arguably) legitimate reason that a corporation or union should be barred from spending money on election-related speech is because this would give its views disproportionate weight in society, and the legislature is seeking to democratize the influence that money can bring to bear upon the electoral process.

The participatory self-government rationale similarly explains the joint majority opinion's rejection of the plaintiffs' argument that the segregated fund requirement for corporate spending on electioneering communications is constitutionally underinclusive because it exempts media corporations' spending on news items and commentary. The Court found the media exception "wholly consistent with First Amendment principles," ${ }^{, 130}$ citing Austin's rejection of a similar argument and a number of federal statutes providing advantages to the institutional press. The Austin Court had praised what it viewed as the press's "unique role ... in 'informing and educating the public, offering criticism, and providing a forum for discussion and debate."”131

The joint majority opinion in McConnell goes further than Austin by stating that Congress may not regulate "financial contributions" to political talk show hosts or newspaper editors "on the sole basis that their activities confer a benefit on the candidate." ${ }^{132}$ This statement suggests that an exception for the institutional press from a separate fund requirement might be not only constitutionally permissible, but constitutionally required, to further the objectives of participatory selfgovernment-the institutional corporate press is simply more worthy of protection than other corporations. ${ }^{133}$

${ }^{130}$ McConnell, 124 S. Ct. at 697.

131 Austin, 494 U.S. at 667 (quoting First Nat'l Bank of Boston v. Bellotti, 435 U.S. $765,781(1978))$.

${ }^{132}$ Mc Connell, 124 S. Ct. at 668 n.51.

${ }^{133}$ If so, it would apparently mark the first time that the Court has recognized special First Amendment protections for the institutional press. See Cohen v. Cowles Media Co., 501 U.S. 663, 669-70 (1991) (stating that Minnesota's enforcement of promis- 
The joint majority opinion contains many more signs of the Court's acceptance of the participatory self-government rationale. The Court not only upheld BCRA against constitutional challenge; it lavished it and prior congressional regulatory efforts with effusive praise as furthering the needs of a well-functioning democracy. Thus, "BCRA is the most recent federal enactment designed to purge national politics of what was conceived to be the pernicious influence of 'big money' campaign contributions." ${ }^{134}$ It followed earlier legislative developments including the enactment of FECA, through which Congress "continued its steady improvement of the national election laws." "135

The joint majority opinion further opines that BCRA's "fidelity" to the "imperatives" of "[p]reserving the integrity of the electoral process, preventing corruption, and sustain[ing] the active, alert responsibility of the individual citizen in a democracy for the wise conduct of the government," "sets it apart from the statute in Bellotti-and, for that matter, from the Ohio statute banning the distribution of anonymous campaign literature struck down in McIntyre v. Ohio Elections Commission." 136 The joint majority opinion never tells us precisely how BCRA passes and the statutes at issue in Bellotti and McIntrye fail to meet these interests. Indeed, the majority never defines the government's interests in preserving the "integrity of the electoral process" or sustaining an "active" and "alert" citizenry. Are these interests subsidiary interests that are protected by the recognized anticorruption rationale, or are they new interests through which the Court may uphold additional campaign finance laws that further the goals of participatory self-government?

A final piece of evidence suggesting that McConnell is a transitional case is found in the Court's description of Buckley's holding striking

sory estoppel against the media "is not subject to stricter scrutiny than would be applied to enforcement against other persons or organizations"); Houchins v. KQED, 438 U.S. 1, 14-16 (1978) ("[U]ntil the political branches decree otherwise, as they are free to do, the media have no special right of access to the Alameda County Jail different from or greater than that accorded the public generally."); Branzburg v. Hayes, 408 U.S. 665, 692 (1972) (denying that "the First Amendment protects a newsman's agreement to conceal the criminal conduct of his source" in a grand jury proceeding); see also Hasen, Rupert Murdoch Problem, supra note 5, at 1657 (discussing the media's potential argument that they are "entitled to greater constitutional protection than the general public").

${ }^{134}$ McConnell, 124 S. Ct. at 644 (internal quotation marks omitted).

${ }^{135} I d$. at 645.

${ }^{136}$ See id. at 696 n.88 (alterations in original, citations and internal quotation marks omitted); see generally McIntyre v. Ohio Elections Comm'n, 514 U.S. 334 (1995). 
down expenditure limits. The joint majority opinion in McConnell accurately recounts the Buckley holding but pointedly fails to recount Buckley's explicit rejection of the equality rationale as a justification for expenditure limits, ${ }^{137}$ that part of Buckley which Justice Breyer had said "cannot be taken literally." ${ }^{138}$ It seems as probable as not that the Court's elisional history was intentional and not inadvertent.

\section{A Note OF CaUtion: ApPlying the Participatory Self- GOVERNMENT RATIONALE IN A RESPONSIBLE MANNER}

\section{A. Missing from McConnell: Careful Balancing and Policing for Self-Interest}

Justice Breyer, in his Shrink Missouri concurrence, admonished that "constitutionally protected interests lie on both sides of the legal equation." ${ }^{139}$ He directed his admonition to those Justices such as Justice Thomas who saw the First Amendment rights of free speech and association as trumping most, if not all, campaign finance regulation. ${ }^{140}$ But the admonition should apply as well to those Justices voting to uphold campaign finance regulation in the post-2000 cases and especially in McConnell, because in their embrace of legislative deference, they have abdicated their responsibility to carefully balance competing constitutional concerns and to police legislatively enacted campaign finance regulations for self-interest.

Justice Kennedy's partial dissent in McConnell sounded incumbency protection as a major theme. "When one recognizes that $\$ \$ 323(\mathrm{a})$, (b), (d), and (f) do not serve the interest the anticorruption rationale contemplates, Title I's entirety begins to look very much like an incumbency protection plan." ${ }^{141}$ Justice Scalia similarly focused on in-

${ }^{137}$ McConnell, 124 S. Ct. at 647 . Chief Justice Rehnquist's opinion for the majority on the Title III and Title IV issues does mention the Court's rejection of the equality rationale in response to the argument of the Adams plaintiffs that an increase in the hard money contribution limits constituted a denial of equal protection. Id. at 708-09 (Rehnquist, C.J.).

${ }_{138}$ Shrink Missouri, 528 U.S. at 402 (Breyer, J., concurring).

${ }^{139} I d$. at 400.

${ }^{140}$ For Justice Thomas, we now know that it is closer to all than most. Justice Thomas alone rejected even the disclosure requirements of BCRA. See McConnell, 124 S. Ct. at 735-36 (Thomas, J., concurring in part and dissenting in part) ("The right to anonymous speech cannot be abridged based on the interests asserted by the defendants.").

${ }^{141} I d$. at 753 (Kennedy, J., concurring in part and dissenting in part). Justice Kennedy pointed in particular to the fact that "Congress exempted its officeholders from the more stringent prohibitions [on solicitations] imposed on party officials." Id. 
cumbency in his separate opinion, ${ }^{142}$ citing to numerous Congressional floor statements that BCRA's purpose in expanding the corporate and union separate fund requirement to electioneering communications was to limit the extent of negative "attack ads." ${ }^{143}$

The joint majority opinion's response to the incumbency argument-tucked into a footnote apparently added to the opinion at the end of the drafting process ${ }^{144}$-is both unsatisfying and disingenuous:

Any concern that Congress might opportunistically pass campaignfinance regulation for self-serving ends is taken into account by the applicable level of scrutiny. Congress must show concrete evidence that a particular type of financial transaction is corrupting or gives rise to the appearance of corruption and that the chosen means of regulation are closely drawn to address that real or apparent corruption. ${ }^{14}$

The response is unsatisfying because it incorrectly assumes that identifying the appropriate level of scrutiny can substitute for a careful balancing and the difficult judgment calls that the Court faces in evaluating campaign finance regulation. ${ }^{146}$ The response is disin-

The majority's response to this particular point was to say that the provisions "allow[] only minimally greater opportunities for solicitation out of regard for the fact that candidates and officeholders, unlike party officers, can never step out of their official roles." Id. at $684 \mathrm{n} .72$ (joint majority opinion); see also id. at 680 ("[N]ational party officers, unlike federal candidates and officeholders, are able to solicit soft money on behalf of nonprofit organizations in their individual capacities."). But the Court never explains how it is that a member of Congress is less able to step out of her official role for purposes of soliciting a contribution to a tax-exempt organization than the Chair of the Democratic National Committee.

${ }^{142}$ See, e.g., id. at 720-21 (Scalia, J., concurring in part and dissenting in part) (asserting that, though "the legislation is evenhanded," it nevertheless benefits incumbents because, when "incumbents and challengers are limited to the same quantity of electioneering, incumbents are favored").

${ }^{143}$ Id. at 727.

${ }^{144}$ I suggest that footnote 72 appeared late because it both misspelled "overruled" as "overrruled" and miscited 2 U.S.C. $\$ 441 \mathrm{i}(\mathrm{e})$ as 42 U.S.C. $\$ 441 \mathrm{i}(\mathrm{e})$. Id. at 684 n.72.

${ }^{145} I d$. at 684 n.72. The joint majority opinion added: "At bottom, Justice Kennedy has long disagreed with the basic holding of Buckley and its progeny that less rigorous scrutiny-which shows a measure of deference to Congress in an area where it enjoys particular expertise-applies to assess limits on campaign contributions." Id.

${ }^{146}$ Cf. Shrink Missouri, 528 U.S. 377, 400 (2000) (Breyer, J., concurring) ("Nor can we expect that mechanical application of the tests associated with 'strict scrutiny'-the tests of 'compelling interests' and 'least restrictive means'-will properly resolve the difficult constitutional problem that campaign finance statutes pose."). Justice Breyer suggested in his Shrink Missouri concurrence that a lax standard of review may provide enough protection in campaign finance cases challenging contribution limits, because deference there "does not risk such constitutional evils as, say, permitting incumbents to insulate themselves from effective electoral challenge." $I d$. at 402. But his reasoning is unclear: certainly a very low contribution limit may benefit incumbents because of 
genuous because, as Part II illustrates, under the post-2000 campaign finance jurisprudence, the Court (1) no longer requires "concrete evidence" of corruption to sustain a campaign finance limit; (2) has elastically redefined "corruption" so as to include even the eventual threat of circumvention of existing law or potential benefit to an officeholder, without requiring any evidence to that effect; (3) has explained that "closely drawn" campaign finance statutes in fact need not be "fine tuned;" and (4) has left open the "appearance of corruption" as a catchall for upholding any campaign finance regulation that fails to meet the test for actual corruption whenever the government can point to potential benefits to officeholders.

The Court should have taken the incumbency question seriously, and more openly and directly addressed the kinds of balancing that appeared to be going on behind the scenes in resolving the BCRA challenges in any case. Instead of doing so, the joint majority opinion repeatedly calls for legislative deference. It is easy to praise the Court's deference in McConnell as a corrective to the Supreme Court's federalism excesses of the last decade. ${ }^{147}$ But blanket calls for deference are misplaced if one takes the goals of participatory selfgovernment seriously.

In engaging in careful balancing and policing for self-dealing under the participatory self-government rationale, there is a place for deference and a place for skepticism. In particular, the Court should defer, within reason, ${ }^{148}$ to the value judgments made by legislative bod-

\footnotetext{
their tendency to be able to raise money more easily, as some have argued was the case with the Missouri limits. See, e.g., Schotland, supra note 15, at 342 ("In short, all Missouri enacted was a low limit on contributions directly to candidates, easily avoided. Strikingly, Missouri has the 10th highest incumbent reelection rate for its legislators, 1980-2001. So much for protecting "the integrity of the electoral process." (footnote omitted)).

${ }^{147}$ See Linda Greenhouse, A Court Infused with Pragmatism, N.Y. TIMES, Dec. 12, 2003, at A38 (" $[\mathrm{I}] \mathrm{t}$ is possible to view [McConnell $]$ as something of a corrective, a pragmatic intervention ... to lower the temperature of an increasingly fraught relationship with another branch of government. 'The court gave Congress space to breathe."' (quoting Yale Law School Professor Robert C. Post)); Cass R. Sunstein, Editorial, In Court v. Congress, Justices Concede One, WASH. PosT, Dec. 21, 2003, at B3 (noting that, prior to McConnell, the Rehnquist Court's "invalidations [of federal legislation] seemed to herald a return to long-discarded ideas about states' rights").

${ }^{148}$ On this important qualifier, see infra Part IV.C (noting that the Court should remain cognizant of the fact that expenditure limits level down the amount of speech to achieve democratic goals).
} 
ies on contested issues of political equality, ${ }^{149}$ but should not defer on a close fit of means and ends. ${ }^{150}$ Leaving such value judgments to the political process better serves the goals of the democratic system by assuring both experimentation and flexibility so as to strengthen democratic institutions.

Judicial deference to legislative value judgments in this area would not be an abdication of the Court's role to protect those speech and association rights protected by the First Amendment. The Court would retain a crucial role in assuring that the means the legislature has put forward to promote equality concerns, such as participatory self-government, are in fact likely to achieve those ends. The purpose of this close scrutiny is to serve as a substitute for a test of legislative motive. Legislators may be tempted to regulate in the name of political equality but really to protect themselves from competition or to further their own agendas. But proof of such motive is often absent, suggesting the means-ends testing as a second best solution. When the means and ends do not match well, the reason may be that the ends asserted are not the ends intended. ${ }^{151}$

\section{B. Reconsidering the Three Examples Under a More Responsible Balancing Approach}

To give a better sense of how the careful balancing approach differs from both Buckley and the deferential approach of the post-2000 cases, I return to the three examples from the McConnell decision first described in Part II: BCRA $\S 323$ (b)'s soft money ban applied to local political parties; concerning corporations and labor unions, the potential overbreadth problems stemming from BCRA $\S 203$ 's segre-

${ }^{149}$ Cf. Shrink Missouri, 528 U.S. at 403 (Breyer, J., concurring) (“[T]he legislature understands the problem-the threat to electoral integrity, the need for democratization-better than do we.")

${ }^{150}$ I first advanced this idea in HASEN, SUPREME COURT \& ELECTION LAW, supra note 13 , at $116-20$.

${ }^{151}$ Of course, in the face of actual evidence of improper legislative motive, the Court should certainly disapprove campaign finance regulation enacted in the name of political equality. For example, in First National Bank of Boston v. Bellotti, 435 U.S. 765 (1978), there was strong evidence that the Massachusetts legislature acted specifically to ban corporate expenditures in ballot measure elections because corporations had been successful in the past in blocking an income tax initiative favored by a majority of legislators (but that required voter approval for enactment). See id. at 826-27 n.6 (Rehnquist, J., dissenting) ("If inquiry into legislative motives were to determine the outcome of cases such as this, I think a very persuasive argument could be made that the General Court ... simply decided to muzzle corporations on this sort of issue so that it could succeed in its desire."). 
gated fund requirement and the apparent lack of an as-applied challenge to the provision; and the Court's failure to consider application of the Austin rationale to labor unions.

Recall that the joint majority opinion explained the decision to uphold the soft money ban's application to local political parties as based not upon any evidence, but upon conjecture that local parties could eventually become conduits for the sale of access to federal officeholders. ${ }^{152}$ In its analysis on this point, the Court correctly deferred to Congress, finding that it was a permissible goal to prevent such sales of access, even if it could not be proven that access in fact led to a change in voting behavior by members of Congress: ${ }^{153}$ it is a reasonable, though contested, political equality determination that access to federal officeholders should not go to the highest bidder. ${ }^{154}$

But it is a much closer question whether Congress should be allowed, consistent with the First Amendment, to place a host of significant federal fundraising limitations on local parties' get-out-the-vote and voter registration activities and local candidates' electioneering activities solely upon the as-of-yet unsubstantiated fear that local parties could become the next conduits for federal corruption. There may be good reason to believe that sale of access through local parties might be less effective than sale through state parties given potential problems of coordination and decentralization, making local parties less valuable to federal officeholders than other means of support. Absent at least some evidence that local political parties posed a danger of undermining participatory self-government unless regulated by Congress, the Court likely should have rejected this aspect of section 323(b), or at least deferred consideration of the question until evi-

${ }^{152}$ See supra notes 96-97 and accompanying text.

${ }^{153}$ Compare McConnell, 124 S. Ct. 619, 750 (Kennedy, J., dissenting in part) (" $[\mathrm{N}] \mathrm{o}$ Member of Congress testified this favoritism [gained from soft money contributions] changed voting behavior."), with id. at 664 (joint majority opinion) ("The evidence connects soft money to manipulations of the legislative calendar, leading to Congress' failure to enact, among other things, generic drug legislation, tort reform, and tobacco legislation." (citations omitted)). Once again, the majority appears to have based a factual finding solely on the evidence of a single judge, Judge Kollar-Kotelly. The majority cited to page 852 of Judge Leon's opinion as support for the evidence, but there Judge Leon wrote: "Testimony from other former Members of Congress describe, at best, their personal conjecture regarding the impact of soft money donations on the voting practices of their present and former colleagues." McConnell, 251 F. Supp. 2d at 852 (Leon, J., concurring in part and dissenting in part).

${ }^{154}$ I defend this point in Hasen, Clipping Coupons, supra note 5, and Hasen, Rupert Murdoch Problem, supra note 5. 
dence could be gathered that local political parties could indeed play this role. ${ }^{155}$

The overbreadth question was similarly more complex than the joint majority opinion admitted. Absent from the overbreadth analysis was some sort of qualitative determination that the extent of the overbreadth was worth sustaining for the sake of a workable campaign finance system. Thus, the majority never considered whether the provision, under Justice Breyer's standard, "strike[s] a reasonable balance between [its] electoral speech-restricting and speech-enhancing consequences." 156 It simply concluded that a "vast majority" of the advertisements were election-related and therefore subject to regulation. ${ }^{157}$

Yet when it comes to overbreadth analysis, "[t]here is no sensible substitute, at least in hard cases, for a forthright judicial balancing." 158 The Court must inquire "whether the state's interest is truly compelling, and, if so, whether that interest justifies as much infringement on, and chilling of, protected speech as the statute effects." ${ }^{, 159}$

Thus, the answer to the overbreadth question for regulating sham issue advocacy depends not only on the percentage of genuine issue advertisements captured but also on the benefits that the legislation hopes to achieve compared to the costs of requiring corporations and unions wishing to run genuine issue ads to do so only through a separate PAC. ${ }^{160}$ Such a balancing of interests no doubt occurred beneath the surface in McConnell, even if the Justices failed to say so explicitly: eight of the nine Justices on the Court were willing to sustain BCRA's basic disclosure rules despite the fact that it applied disclosure rules to the exact same percentage of genuine issue advertisements and despite the fact that disclosure rules no doubt burden First Amendment rights of speech and association. ${ }^{161}$ Yet the Court split 5-4 on ex-

${ }^{155}$ The Court appeared to defer consideration of other aspects of BCRA pending rulemaking by the Federal Communications Commission. McConnell, 124 S. Ct. at 718 (Breyer, J.).

${ }_{156}$ Breyer, supra note 3, at 253.

${ }^{157}$ Mc Connell, 124 S. Ct. at 696.

${ }^{158}$ Richard H. Fallon, Jr., Making Sense of Overbreadth, 100 YALE L.J. 853, 894 (1991) (footnote omitted).

${ }^{159} I d$. at 895.

${ }^{160}$ See Hasen, supra note 108, at 1801 (“[I]n evaluating each case, there seems no substitute for looking at the benefits that the legislation hopes to achieve in regulating sham issue advocacy on the one hand with the costs of overbreadth on the other.").

${ }^{161}$ All of the Justices except for Justice Thomas joined in Justice Rehnquist's opinion with respect to BCRA Title III, other than sections 304, 305 and 307. See McConnell, 124 S. Ct. at 640 (summarizing the votes of the Justices). 
tending the corporate and union segregated fund requirement to electioneering communications.

For reasons I have explored elsewhere ${ }^{162}$ and will not repeat here, I believe that Congress had a good reason to extend Austin's rationale to electioneering communications, despite the overbreadth problem. But the issue is a difficult one. On the one hand, effective campaign finance regulation had become all but impossible under Buckley's express advocacy (or "magic words") test. On the other hand, there is something troubling about limiting the ability of corporations and labor unions to engage in political speech unrelated to elections at the time when the corporation or union may be most likely to command an officeholder's attention. The McConnell Court's decision, though controversial, is certainly defensible under a participatory selfgovernment rationale.

What is indefensible, however, is the McConnell Court's dismissive approach to the question. Even more indefensible is the Court's failure to explicitly leave open (and perhaps affirmatively to exclude) the possibility of an as-applied challenge for a corporation or labor union that wishes to engage in genuine issue advocacy using corporate or union funds. ${ }^{163}$

Finally, on the issue of including unions under the Austin rationale, it is hardly clear that unions pose the same dangers as corporations under the participatory self-government rationale. ${ }^{164}$ Perhaps the Court could have constructed a rationale based on the idea that parity between unions and corporations is somehow necessary for participatory self-government in the United States. ${ }^{165}$ But the Court of-

162 See Hasen, supra note 108, at 1803 ("[T] he corrosive effects of corporate wealth on the political process do not differ when the corporation sponsors a 'Defeat Bonior' advertisement rather than a sham issue advocacy advertisement criticizing Bonior's drug policy.").

${ }^{63}$ See supra note 120 and accompanying text (noting that the joint majority opinion in McConnell suggests that there might be some "as applied" challenges to BCRA); cf. Hasen, supra note 108, at $1802 \mathrm{n} .114$ (endorsing possibility of an as-applied challenge in appropriate circumstances).

${ }^{164}$ See supra note 125 and accompanying text (quoting Austin's reasons for the permissibility of not including unions in the corporate segregated fund requirement for election-related speech).

${ }^{165}$ As Dan Lowenstein observed before McConnell: "[T] he tradition over the past half century of treating unions and corporations alike under federal and many state election laws might lead the Court to uphold a ban on independent expenditures by unions even if the logic of the decided cases suggests otherwise." Lowenstein, supra note 54, at $386 \mathrm{n} .21$. The unions themselves did not push the distinction between corporations and unions, see, e.g., Reply Brief of AFL-CIO Appellants/Cross-Appellees, McConnell v. FEC (No. 02-1755), available at 2003 WL 22002434, perhaps out of fear 
fered no such rationale; indeed, it skipped over the question entirely as though it were self-evident.

\section{The Future Constitutionality of Expenditure Limitations in the Post-McConnell Supreme Court}

\section{Why the Court Might Be Poised to Uphold Some Expenditure Limits}

Perhaps the ultimate question about the direction of the post2000 jurisprudence is whether it may lead the Supreme Court to uphold expenditure limits outside the corporate and union context. After Shrink Missouri was decided, but before Colorado II, Beaumont, the passage of BCRA, or McConnell, I suggested that the Court's new deferential jurisprudence could indeed provide for such a possibility. ${ }^{166}$ After recounting the spending of the Wyly brothers on anti-McCain sham issue advertisements during the New York Republican presidential primary, ${ }^{167}$ I wrote:

Suppose Congress, citing the Wyly advertisements, passed a law regulating such advertisements. Congress could redefine "express advocacy" or electioneering to include [the bright-line test that had been proposed in the McCain-Feingold bill and later adopted in BCRA]. It could then subject independent expenditures to dollar limitations, as the FECA did before that portion of it was struck down. A Supreme Court hospitable to such a new law could say that Buckley's decisions regarding expenditures and issue advocacy were made under the pressure of the 1976 election, before there had been an opportunity to gather evidence on the corruption and the appearance of corruption stemming from independent expenditures and before those engaged in electioneering routinely evaded the FECA.... The Court could then say that evidence now demonstrates that such expenditures are meant to influence the outcome of electoral campaigns. Further, even absent evidence of coordination, voters may believe that Wyly will "call the tune" for Bush; no

that Congress would respond to a decision striking down the application of section 203 to labor unions by repealing its application to corporations.

${ }^{166}$ See Hasen, supra note 58, at 500-09 (analyzing the Supreme Court justices' likely interpretations of Shrink Missouri and predicting the demise of Buckley).

${ }^{167} I d$. at 503. The Wyly brothers are longtime Bush supporters from Texas. See Richard A. Oppel, Jr. \& Richard Pérez-Peña, Role in Ads Puts Focus on Bush Friend, N.Y. Times, Mar. 6, 2000, at A16 (noting that the Wyly brothers were among George W. Bush's most generous campaign contributors during the primary). The McConnell opinion mentions the activities of the Wyly brothers as well. See McConnell, 124 S. Ct. at 691 ("Curiously, Plaintiffs want to preserve the ability to run these [sham issue] advertisements while hiding behind dubious and misleading names like ... 'Republicans for Clean Air' (funded by brothers Charles and Sam Wyly).”) (citation omitted). 
proof of a quid pro quo is required under Shrink Missouri, only the possibility that Bush might be "too compliant" with the interests of his benefactor.

The Court might not require much evidence from Congress if it believed these claims were "neither novel nor implausible." Perhaps it would be enough to point to a New York Times profile of Wyly in which the Texas director of consumer group Public Citizen recounted how Wyly, who has an interest in a company investing in renewable energy, had offered to help convince Governor Bush to include a provision in an energy bill requiring that certain coal plants reduce their pollution. The director said "the episode 'is a crystalline example of what donors get from Bush for their contributions-an opportunity to make their pitch.",168

Four years later, with McConnell making up the fourth in the New Deference Quartet, this scenario seems increasingly more likely. Indeed, the kind of evidence I cited in my 2000 article reads very much like the kind of evidence cited by the McConnell joint majority opinion to support the soft money bans. To be sure, such a change in campaign finance jurisprudence is not going to happen until five Justices are comfortable overruling the central aspect of Buckley, which struck down expenditure limitations. ${ }^{169}$ But the reasoning of the post-2000 cases applies, without much of a stretch, to the Court upholding expenditure limitations.

If the relevant anticorruption question from McConnell is whether there are sufficient potential benefits to federal officeholders, ${ }^{170}$ then surely some limits on independent expenditures could be warranted. It is no more "novel" or "implausible" that large independent spending supporting a federal officeholder can benefit that officeholder and secure access to her than that soft money raised by local political parties, ${ }^{171}$ or spent by local officials on certain public communications, ${ }^{172}$ can benefit the federal officeholder and secure access to her.

To be sure, the McConnell Court tries to rein in the potential benefit idea by pointing to the "close relationship" federal officeholders

${ }^{168}$ Hasen, supra note 58, at 503-04 (citations omitted).

${ }^{169}$ Cf. id. at 504 ("The Court would not even need to expressly overrule Buckley... instead, it could distinguish Buckley on grounds that new evidence is available that was not available in Buckley that would justify a law even under Buckley's strict scrutiny-like standard for expenditures.").

${ }^{170}$ See supra note 98 and accompanying text.

${ }^{171}$ BCRA, sec. 101, § 323(b).

${ }^{172}$ BCRA, sec. 101, § 323(f). 
and candidates have with their parties. ${ }^{173}$ Corruptive potential must accompany the potential to benefit officeholders. But the Wyly brothers had their own close relationship with Bush, and the McConnell Court itself detailed the connections between federal officeholders and a number of nonprofit political organizations that might engage in independent spending benefiting these officeholders. It might be that such organizations would fall on the same side of the line as the parties, with "political talk show hosts" and "newspaper editors" on the other side of the line. ${ }^{174}$ The organizations might not be, like parties, "uniquely positioned to serve as conduits for corruption;", but rather, as organizations that have eliminated the middleman, they are uniquely positioned to gain access to the federal officeholder by attracting attention through their independent spending.

There is even a suggestion in McConnell that the Court might uphold expenditure limits in the absence of a potential benefit to officeholders. This point would be especially important if state or local governments attempted-contra Bellotti and CARC—-to limit spending in ballot measure campaigns, where the possibility of corrupting an officeholder is attenuated, if not absent. ${ }^{176}$

Much turns here on interpretation of McConnell's cryptic, but crucially important, footnote 48 of the joint majority opinion, ${ }^{177}$ where the Court explained (or rather reinterpreted) its earlier decision in $C M A .^{178} C M A$ involved a challenge to FECA's $\$ 5000$ limit on contribu-

${ }^{173}$ McConnell, 124 S. Ct. at 668 n.51. The joint majority opinion also never explicitly endorses the argument put forward by the defenders of section 203 that Congressional power extends to any advertisement that may affect federal elections, whether or not the advertiser so intends. Cf. id. at 770 (Kennedy, J., dissenting in part).

${ }^{174}$ See id. at 668 n.51 ("We agree with The Chief Justice that Congress could not regulate financial contributions to political talk show hosts or newspaper editors on the sole basis that their activities conferred a benefit on the candidate.").

${ }^{175} I d$.

${ }^{176}$ It is attenuated because officeholders sometimes link their fortunes to initiatives. Richard L. Hasen, Parties Take the Initiative (and Vice Versa), 100 COLUM. L. REv. 731, 744 n.58 (2000) (describing several California candidates' use of the initiative process); Elizabeth Garrett, Democracy in the Wake of the California Recall, 153 U. PA. L. REV. 239, $241 \&$ n.9 (2004) (making a similar point in the context of the California recall election).

177124 S. Ct. at 665 n.48. I thank Marty Lederman for first causing me to consider the importance of footnote 48 .

${ }^{178} 453$ U.S. 182 (1981). A four-Justice plurality opinion as well as Justice Blackmun's separate concurring opinion appeared to focus solely on the pass-through problem. Id. at 198 (plurality opinion) ("If appellants' position ... is accepted, then both these contribution limitations could be easily evaded."); $i d$. at 203 (Blackmun, J., concurring) ("I conclude that contributions to multicandidate political committees may be limited to $\$ 5,000$ per year as a means of preventing evasion of the limitations [those 
tions to PACs. The McConnell Court stated that the statute at issue in $C M A$ was justified not only to prevent "pass-throughs" of contributions to federal candidates but also as an appropriate measure to limit contributions funding "express advocacy and numerous other noncoordinated expenditures." 779 The footnote's statement that it could be consistent with the First Amendment to limit contributions funding independent expenditures suggests that it is perhaps also consistent with the First Amendment to limit independent expenditures themselves. ${ }^{180}$

The extent of footnote 48's reach is unclear. On what basis might contributions to fund independent expenditures be limited? Perhaps the Court's point in the footnote is simply a variation of the potential benefits theme: contributions funding independent expenditures may benefit officeholders and secure access to them. If that is correct, however, independent expenditures themselves in candidate elections may serve the same purpose, and the entire Buckley edifice, built on a foundation of a contribution-expenditure dichotomy, falls.

On the other hand, perhaps the Court had some other idea in mind as to why such a law would survive First Amendment challenge. For example, perhaps such laws might be justified on political equality grounds. If it turns out that the reasoning is not tied to potential benefits of officeholders or the potential to corrupt them, then application of expenditure limits even in ballot measure campaigns seems constitutionally possible. Again, the Buckley edifice falls. Is that what the Court really intended buried in a few sentences of a footnote in one of the longest cases in Supreme Court history?

under 2 U.S.C. $\$ \S 441$ (a) (1) (A) \& 441(a) (a) (3) ], on contributions to a candidate or his authorized campaign committee...."). Justice Blackmun then went on to "stress ... that a different result would follow if [the statute] were applied to contributions to a political committee established for the purpose of making independent expenditures, rather than contributions to candidates." Id; see also Lincoln Club v. City of Irvine, 292 F.3d 934, 938 (9th Cir. 2002) (raising but not resolving the constitutionality of limiting contributions to independent expenditure committees).

The McConnell Court pointed also at Buckley's decision to uphold a $\$ 25,000$ aggregate yearly limit on individual contributions to candidates' political committees and party committees. McConnell, 124 S. Ct. at 665 n.48 (citing Buckley, 424 U.S. at 38).

${ }^{179}$ McConnell, 124 S. Ct. at 665 n.48.

${ }^{180}$ The question is at the heart of regulating 527 committees that have been active in the 2004 presidential election. See Richard L. Hasen, Commentary, A GOP Flip-Flop on Political Ads, L.A. Times, Mar. 14, 2004, at M5 ("The really interesting question is whether these ads should be illegal. The question goes to the heart of why we regulate campaign money in the first place."). 
2. Examining the Constitutionality of Expenditure Limits Under the Participatory Self-Government Rationale

Although it is now easy to imagine how the McConnell majority could write an opinion upholding an expenditure limit under an anticircumvention/anticorruption/potential benefit theory, one hopes the Court would not do so without engaging in careful balancing and policing for legislative self-interest. Expenditure limits may tend to benefit incumbents by giving them a chance to limit funds spent opposing them. Even putting aside self-interest, expenditure limits raise troubling questions under the participatory self-government rationale to the extent they inhibit vibrant election-related participation by a wide group of nongovernmental actors. The McConnell Court may have oversold the value of the institutional press in fostering this debate and undersold the value of corporate and other speech in Beaumont. ${ }^{181}$

These points raise difficult questions involving theory (what is the best form of representative government?), facts (to what extent do expenditure limits inhibit robust political speech?), and division of labor (to what extent should the courts defer to legislatures, which have greater expertise in political affairs but also a serious agency problem?).

At bottom, the problem with expenditure limits is that they achieve political equality by leveling down the amount of speech. ${ }^{182}$ Leveling down political speech seems antithetical to the participatory self-government rationale. Expenditure limits only make sense from the point of view of participatory self-government when they are coupled with level-up mechanisms that increase the vibrancy and diversity of election-related speech. Full public financing of campaigns, especially through a market-mimicking voucher program, could well accomplish these goals. ${ }^{183}$ Without such a level-up mechanism, the Court should be wary of deferring to the genuinely-made value judgment of a legislative body that would impose expenditure limits in the name of furthering democratic values.

${ }^{181}$ See supra notes 79-80 and accompanying text (analyzing the holding and implications of Beaumont).

${ }^{182}$ See Joel L. Fleishman \& Pope McCorkle, Level-Up Rather than Level-Down: Towards a New Theory of Campaign Finance Reform, 1 J.L. \& POL. 211, 247 (1984) (criticizing the "inegalitarian policy outcomes" of a leveling-down approach).

${ }^{183}$ See Hasen, Clipping Coupons, supra note 5, at 21 (defending voucher proposal that both levels-up and levels-down). 


\section{CONCLUSION}

Reformers have much to cheer in the McConnell decision. It is essentially a green light to enact any kind of rational campaign finance plan in candidate elections-at least any rational plan that does not include expenditure limits applied outside the corporate/union context or limits applied to media corporations. But after the cheering subsides, the reform community needs to take a hard look at what McConnell and the other post-2000 jurisprudence have wrought. Few reformers will be cheered in the long run by campaign finance laws that are indeed intended to limit competition or that balance interests (expressly or not) in ways that squelch rigorous debate about political (including electoral) issues.

In the short term, the job of balancing and policing will fall to legislatures and to the public interest organizations that monitor them. Lower courts showing fidelity to McConnell will have a difficult time striking down most campaign finance regulation, and the possibility of abuse, especially on the state and local level, seems apparent.

In the long term, the Court will have to consider whether the considerable deference advanced in McConnell does an adequate job of protecting constitutional interests on both sides of the legal equation. After pushing the point for many years that the First Amendment is not everything, the reform community must admit that it is something: a value that must be taken into account, not only in balance with anticorruption measures, but also in assuring true participatory self-government. 